\author{
NBER WORKING PAPER SERIES \\ ON \\ HISTORICAL FACTORS IN LONG RUN GROWTH
}

\title{
AGGREGATE PRICE SHOCKS AND FINANCIAL INSTABILITY: \\ AN HISTORICAL ANALYSIS
}

\author{
Michael D. Bordo \\ Michael J. Dueker \\ David C. Wheelock
}

Historical Paper 125

\author{
NATIONAL BUREAU OF ECONOMIC RESEARCH \\ 1050 Massachusetts Avenue \\ Cambridge, MA 02138 \\ April 2000
}

We thank Alton Gilbert, Bob Rasche, Joshua Rosenbloom, Anna Schwartz, Rick Sullivan, Tom Weiss and workshop participants at the University of Kansas for comments on an earlier draft, and Heidi L. Beyer for research assistance. Opinions expressed in this paper are not necessarily official positions of the Federal Reserve Bank of St. Louis or the Federal Reserve System. The views expressed herein are those of the authors and do not necessarily reflect those of the National Bureau of Economic Research.

(C) 2000 by Michael D. Bordo, Michael J. Dueker, and David C. Wheelock. All rights reserved. Short sections of text, not to exceed two paragraphs, may be quoted without explicit permission provided that full credit, including (C) notice, is given to the source. 
Aggregate Price Shocks and Financial Instability: An Historical Analysis

Michael D. Bordo, Michael J. Dueker, and David C. Wheelock

NBER Historical Paper No. 125

April 2000

Development of the American Economy

\section{ABSTRACT}

This paper presents empirical evidence on the hypothesis that aggregate price disturbances cause or worsen financial instability. We construct two annual indexes of financial conditions for the

United States covering 1790-1997, and estimate the effect of aggregate price shocks on each index using a dynamic ordered probit model. We find that price level shocks contributed to financial instability during 1790-1933, and that inflation rate shocks contributed to financial instability during 1980-97. Our research indicates that the size of the aggregate price shocks needed to substantially alter financial conditions depends on the institutional environment, but that a monetary policy focused on price stability would be conducive to financial stability.

Michael D. Bordo

Department of Economics

Rutgers University

New Jersey Hall

New Brunswick, NJ 08903

and NBER

bordo@fas-econ.rutgers.edu

David C. Wheelock

Research Department

Federal Reserve Bank of St. Louis

P.O. Box 442

St. Louis, MO 63166
Michael J. Dueker

Research Department

Federal Reserve Bank of St. Louis

P.O. Box 442

St. Louis, MO 63166 


\section{Aggregate Price Shocks and Financial Instability: An Historical Analysis}

\section{INTRODUCTION}

The notion that central banks should act as lenders of last resort is not controversial. How best to carry out that responsibility is, however, not widely agreed upon. One view holds that the financial system is inherently fragile, and a central bank should forego other objectives, such as preventing inflation, when financial instability threatens. An alternative view argues that by controlling inflation a central bank will in fact promote financial stability. Anna Schwartz $(1988 ; 1995)$, for example, contends that financial instability has often been caused by monetary policies that cause fluctuations in the rate of inflation. She argues that monetary policy should focus exclusively on maintaining price stability.

A few countries, e.g., Canada and New Zealand, have recently made inflation control the paramount objective of their central bank's monetary policy, and the Maastricht Treaty, which established monetary union among eleven European Community countries, specifies control of inflation as the principal objective for the European Central Bank. Most countries, however, including the United States, assign their central banks multiple objectives, such as full employment and financial stability, as well as inflation control. Implicitly, the specification of multiple objectives for monetary policy assumes tradeoffs between those goals - that a country might have to accept higher inflation, at least temporarily, to maintain financial stability, for example.

This paper investigates the historical association between aggregate price and financial stability to shed light on the question of whether a commitment to price stability is likely to enhance or lessen financial stability. Specifically, we use data for the United States from 1790 to 1997 to test the hypothesis that aggregate price disturbances cause or worsen financial instability. Unanticipated aggregate price declines might increase financial distress by leaving some borrowers with insufficient income to repay contracted nominal debt. Thus unanticipated aggregate price declines would increase insolvency and default rates. Positive aggregate price 
shocks, on the other hand, might cause default rates to fall below expectations, and could encourage financial expansion if borrowers and lenders are unable to distinguish changes in relative prices from changes in the aggregate price level. Financial expansion based on aggregate price misperceptions can lead to resource misallocation, however, and thereby worsen financial distress associated with subsequent unanticipated aggregate price declines.

In the gold standard era (roughly 1790-1933), unanticipated movements in the price level best represent price shocks, whereas the persistence of inflation since 1933 led us to examine the impact of unanticipated inflation on financial conditions. We use the term "aggregate price shock" to refer to unanticipated movements in either the price level or the inflation rate.

In the absence of consistent time series measures of aggregate financial conditions over a long period, we construct two annual indexes of financial conditions from both quantitative and narrative sources. We use a dynamic time series probit model to estimate the impact of aggregate price shocks on financial conditions, as reflected in the two indexes. We also regress the four series used to construct the quantitative index on aggregate price shocks to confirm that the relationship between aggregate price shocks and the index is present in its constituent series. We control for both liquidity and real output growth, and test whether relationships changed with changes in monetary regime. Our objective is to shed light on the extent that aggregate price disturbances exacerbate financial instability, and whether the relationship between such disturbances and financial conditions is affected by the institutional environment.

We begin by outlining why aggregate price shocks might cause or worsen financial instability. We then discuss how one might identify the impact of price or inflation disturbances on financial conditions empirically, and describe the construction of two new annual indexes of financial conditions. Next, we describe the dynamic time series probit model used in the estimation and present empirical estimates of the impact of price level and inflation shocks on financial variability, as reflected in the indexes. We conclude by summarizing and discussing implications of our findings. 


\section{AGGREGATE PRICE SHOCKS AND FINANCIAL INSTABILITY}

Financial instability can have either monetary or non-monetary causes and may be solely domestic or spread among countries. In the United States, the $19^{\text {th }}$ and early $20^{\text {th }}$ centuries were punctuated by banking panics - episodes of widespread panic among depositors leading to bank runs. Banks responded to panics by suspending cash payments, and over time bank clearinghouses became adept at meeting the liquidity needs of their members by issuing clearinghouse loan certificates for use in making interbank payments and providing additional currency to meet the demands of bank customers (see, e.g., Dwyer and Gilbert, 1989). Still, banking panics were a principal cause of monetary contraction, deflation, and declines in real economic activity in the $19^{\text {th }}$ and early $20^{\text {th }}$ centuries (Friedman and Schwartz, 1963).

Whereas it is well understood that banking panics can contract the price level and economic activity, falling prices (or a falling inflation rate) by themselves can be a source of financial distress. Because debt contracts typically are written in nominal, fixed rate terms, a decline in the price level increases the real cost of servicing outstanding debt, which can increase loan defaults and bankruptcies, and in turn put pressure on lenders. Even a decline in the rate of inflation can cause distress if the decline is unexpected and not hedged, because some borrowers will have insufficient revenue to service debt that could have been repaid in the absence of disinflation.

Fisher $(1932,1933)$ was among the first to describe the impact of a falling price level on financial conditions in a business cycle framework. According to Fisher, business cycle upturns are triggered by exogenous factors that provide new, profitable opportunities in key sectors of the economy. Rising prices and profits encourage more investment and also speculation for capital gains. Debt finance through bank loans increases deposits and the money supply, and raises the price level. A general optimism or euphoria takes hold, which increases monetary velocity and further fuels the expansion, while rising prices encourage further borrowing by reducing the real value of outstanding debt. 
The process continues until a general state of "overindebtedness" is reached, that is, the point at which individuals, firms, and banks generate insufficient cash flow to service their liabilities. At this point, any shortfall in the price level from its expected value, regardless of cause, will leave borrowers unable to service their debts and lead to distress selling. As loans are extinguished, bank deposits and the money supply decline, further lowering the price level. Deflation increases the real burden of remaining debt, leading to further bankruptcies and declining economic activity - a process referred to as "debt-deflation." The process continues until either widespread bankruptcy has eliminated the overindebtedness or a reflationary monetary policy has been adopted. Once recovery begins, however, the whole process will repeat itself.

Schwartz $(1988,1995,1997)$ offers an alternative explanation, focused explicitly on monetary policy, of how aggregate price instability can lead to financial instability. Schwartz contends that when monetary policy produces fluctuations in the inflation rate, information problems associated with evaluating alternative investments are made worse which, in turn, increases financial instability:

Both [borrowers and lenders] evaluate the prospects of projects by extrapolating the prevailing price level or inflation rate. Borrowers default on loans not because they have misled uninformed lenders but because, subsequent to the initiation of the project, authorities have altered monetary policy in a contractionary direction. The original price level and inflation rate assumptions are no longer valid. The change in monetary policy makes rate-of-return calculations on the yield of projects, based on the initial price assumptions of both lenders and borrowers, unrealizable. (Schwartz 1995, p. 24)

Schwartz does not model formally how changes in the inflation rate can lead to financial instability, but her description fits well with the "monetary misperceptions" model of Lucas $(1972,1973)$. In that model, individuals are unable to distinguish with certainty shifts in relative prices from changes in the aggregate price level. This uncertainty can lead to resource misallocation, which is corrected only once the true nature of a price change becomes known. Thus, for example, a firm might increase its production in response to an apparent increase in demand for its product as reflected by an increase in the market price. If, however, the producer 
understood that the price increase merely reflected an increase in the prices of goods and services generally, and not a change in relative prices in favor of the firm's output, the producer will likely not find it profitable to increase output. Uncertainty about whether the change in one price reflects a shift in relative prices or simply a change in the aggregate price level can thus cause a misallocation of resources.

This model is easily extended to incorporate financial decisions. Uncertainty about the nature of price changes can lead to bad forecasts of real returns to investment projects and, hence, to unprofitable borrowing and lending decisions. When borrowers and lenders forecast returns based on incomplete information or uncertainty about the future level of prices, mistakes can be made that affect borrower defaults ex post. Inflation tends to encourage overly optimistic forecasts of real returns and, thus, can lead to "lending booms," both because of misperceptions regarding the nature of individual price changes and because the default-risk premiums that lenders require may decline when inflation is expected to continue. By the same token, disinflation and, especially, deflation may lead to overly pessimistic forecasts or an increase in risk premiums and hence discourage the financing of projects that might otherwise be funded. ${ }^{1}$

When not fully anticipated or hedged, a change in the inflation rate can cause the net realized real return to investment to deviate from what had been expected. Default rates in debt markets can thus be affected. An unanticipated disinflation, for example, can increase default rates by causing realized borrower incomes to fall below expectations. Although disinflation causes the real income to lenders on loans that do not default to exceed expectations, an increase in default rates could more than offset this gain and result in significant distress for lenders. In the aggregate, financial instability is likely to be associated with disinflation because some projects will generate sufficient income to repay loans only if the rate of inflation equals or exceeds the rate that had been expected when the loans were made. 
Higher than anticipated inflation, by contrast, can cause financial exuberance. Lending booms can result if positive aggregate price disturbances cause borrowers and lenders to form optimistic expectations about future real returns to projects because of their inability to distinguish shifts in relative prices from changes in the aggregate price level. Such financial exuberance can last only until the true path of aggregate prices is realized. Thus, for aggregate price disturbances to cause or worsen financial instability, fluctuations in the inflation rate must, to some extent, be unexpected, and borrowers and lenders must be unable to hedge completely all possible inflation outcomes. If all movements of the inflation rate are fully anticipated, or if individuals can fully insure themselves against all such movements, then inflation will not exacerbate financial instability. Neither condition is likely ever to hold completely, of course, but the better anticipated inflation is, or the more able people are to insure against unfavorable outcomes, the less impact price level variability is likely to have on the stability of the financial system. $^{2}$

A country's institutional environment can affect the form and possibly the severity of financial instability associated with either a real or an aggregate price shock. Banking panics, for example, are much less likely to occur in the presence of an effective lender of last resort. Similarly, high bank failure rates are less likely in systems dominated by large, branching banks, than in unit banking systems. Nevertheless, regardless of the institutional environment, aggregate price instability can still increase borrower defaults, and thereby reduce banking system profits. Financial market structure and regulations can affect the nature of financial instability, and

\footnotetext{
1 In addition to causing mistakes that increase default rates, uncertainty about future inflation can add to the cost of finance because lenders may require an inflation risk premium on interest rates that would not exist in the absence of inflation uncertainty.

2 Although Schwartz emphasizes how inflation increases the difficulty of projecting real returns for both borrowers and lenders, variability in the price level, according to Schwartz (1988, p. 49), can also worsen problems associated with asymmetric information between borrowers and lenders because "fraud and mismanagement are more likely to gain ground in conditions of price variability, and institutions of unimpeachable standards of risk management may make judgments that later turn out to be mistaken, if not disastrous."
} 
perhaps even lessen the effects of inflation shocks, but aggregate price instability will tend to exacerbate financial instability regardless of the institutional environment.

Similarly, the contribution of aggregate price stability to stability of the financial system depends neither on the cause of specific price level movements nor on the nature of the monetary regime, except insofar as they affect the extent that changes in aggregate prices are anticipated. For example, an abrupt decline in inflation following a sustained price level increase will likely contribute to financial distress regardless of whether a country has a gold standard or a fiat monetary system.

Throughout much of the $19^{\text {th }}$ and $20^{\text {th }}$ centuries, the United States was on a gold standard of one sort or another. Under a gold standard, real shocks to the demand or supply of gold cause changes in the money stock and, over the long-term, the price level. The underlying shock might be an adverse movement in the trade balance, for example, leading to a gold outflow, monetary contraction and if sustained, a decline in the price level. There may well be theoretical reasons to not offset real shocks of this sort - the classical "rules of the game," for example, held that gold flows should not be offset, and that the price level should be permitted to adjust to restore equilibrium in the international gold market. Nevertheless, an unstable price level may well increase financial instability.

Even if there are reasons to permit some movement in aggregate prices, a finding that financial distress is worsened by aggregate price instability would suggest that financial instability could be lessened by limiting aggregate price disturbances, and that price and financial stability should be considered complementary, rather than competing policy objectives. We now turn to the historical record to gauge whether there may be support for the proposition that aggregate price instability exacerbates financial instability in general.

\section{EMPIRICAL ANALYSIS}

Our conjecture is that unanticipated movements in the aggregate price level or inflation rate destabilize financial conditions. Negative aggregate price shocks will cause financial distress 
by increasing insolvency and default rates above "normal" levels. Positive aggregate price shocks, on the other hand, will temporarily reduce insolvency and default rates.

The nature of aggregate price disturbances depends on whether the monetary regime is based on a commodity (such as gold) or a fiat regime. Under the gold standard, the price level had a persistent stochastic trend because real shocks to the demand or supply of gold caused changes in the money stock and, over the long-term, the price level (Bordo and Schwartz, 1999). We decompose the price level into anticipated and unanticipated components using a trend-cycle decomposition (details can be found in Appendix A.)

Inflation has become increasingly persistent since the establishment of the Federal Reserve System in 1914 (Barsky, 1987). This period has witnessed the decline and eventual abandonment of the gold standard in favor of a government managed fiat standard. A substantial shift in regime occurred in 1933 with suspension of the gold standard (Calomiris and Wheelock, 1998). Since then, the price level has risen almost continuously and aggregate price shocks are best measured in terms of unanticipated inflation. Hence, for this regime, we apply the trendcycle decomposition to estimate inflation (as opposed to price level) shocks for use in the econometric model.

\section{Measuring Financial Conditions}

We measure financial conditions with two indexes, a "quantitative" index and a “qualitative" index. Our quantitative index, covering the period 1870-1997, is based on annual observations on business and bank failure rates, an ex post real interest rate and an interest rate

quality spread. To extend our analysis to the period before such data are available, we construct a qualitative index from narrative sources covering the period 1790-1869. As a robustness check, we extend the qualitative index through to 1997 and estimate our empirical model on both the qualitative and quantitative indexes separately. Table 1 presents our two indexes of financial conditions. For each index, each year is placed into one of five categories, from "severe distress" to "financial euphoria." The number of years in each category is noted in parentheses. 


\section{Quantitative Index}

The quantitative index provides a means of capturing in a single variable the different aspects of financial conditions reflected in the four variables that make up the index. For example, it treats a year with severe banking distress and a high business failure rate as having more severe financial distress than a year with severe banking distress but few business failures. For 1870-1933, the index is based on four series: a bank failure rate, a business failure rate, an ex post real interest rate and an interest rate quality spread (sources and definitions are available in Appendix A). ${ }^{3}$ Because of the minimal number of bank failures after the Great Depression, for 1934-97 we dropped the bank failure rate in favor of a series on bank loan charge-offs. Chargeoff data are not available prior to 1934.

In general, financial conditions are likely to be reflected well by farm and other business failures, measures of banking conditions and various financial market indicators. High rates of firm or bank failures reflect unrealized income expectations and borrower defaults. Bank failure rates, in particular, however, can be affected by regulation and market structure. For example, the Canadian banking system's oligopolistic structure and close ties to the government probably explain why Canada had no bank failures during the Great Depression, despite suffering severe financial distress in the form of firm and household bankruptcies. Similarly, in the United States, the introduction of federal deposit insurance and imposition of barriers to entry and other regulations in the 1930s probably lowered the number of bank failures that would result from a given-sized macroeconomic shock. By including multiple measures of financial conditions in our index, we reduce the influence of such structural breaks in the relationship between aggregate price shocks and financial conditions.

In addition to business and bank failure rates, we include an ex post real interest rate and an interest rate quality spread in our index. The disinflationary period of the early $1980 \mathrm{~s}$ 
witnessed unusually high real interest rates and interest rate quality spreads. High real interest rates increase the burden of debt on borrowers and may increase the likelihood of loan defaults.

Increases in observed real interest rates during disinflationary periods may reflect expectations that disinflation is only temporary. After some 15 years of rising inflation before 1980, it might have been reasonable to expect that inflation would also be high during the 1980 s that is, to doubt the credibility of the Federal Reserve's pledge to reduce inflation. Hence, lenders demanded high nominal interest rates to compensate for expected inflation, and (some) borrowers were willing to pay those rates, such that equilibrium nominal rates were high relative to current inflation. Because inflation did come down, and stayed down, ex post real interest rates were high. Consequently default rates were unusually high. If observed high real rates reflected similar expectational errors in other periods, we would expect the real rate to be a reasonable proxy of financial conditions. ${ }^{4}$

The difference in yields on low and high-quality bonds is another possible measure of financial conditions. Friedman and Schwartz (1963) and Mishkin (1991) found that quality spreads historically have reflected financial turbulence. More recently, in the unsettled period following the Russian government's debt default and devaluation in August 1998, spreads between yields on corporate bonds, especially those issued by low-rated firms, and U.S. Treasury securities increased sharply. This was widely interpreted as reflecting a flight to quality in the wake of increased uncertainty about foreign economies generally, and ultimately about the continued strength of the U.S. economic expansion. Quality spreads tend to increase during recessions, reflecting the higher default rates of firms during business cycle downturns. Similarly, by redistributing wealth from debtors to creditors, unexpected deflation (or

\footnotetext{
3 Because of the bank holiday, data on bank failures for 1933 are not comparable with those for other years. For 1933, therefore, our quantitative index is based only on the business failure rate, the real interest rate and the quality spread.

4 The observed real rate is simply the nominal interest rate minus the current inflation rate, so a negative correlation between the measured real rate and inflation is not surprising. The nominal interest rate does not adjust fully to changes in the inflation rate simply because some changes are unanticipated or, especially before
} 
disinflation) reduces the net worth of borrowers and thereby causes markets to demand higher yields on risky debt than on low-risk securities. ${ }^{5}$

We constructed the quantitative index as follows: For each series, we computed the differences between annual observations and the series median for the subperiod, divided by the subperiod standard deviation. These standardized differences were summed across the four series for each year. We classify years in which the summed differences exceed $+/-1.5$ standard deviations from the overall mean as years of "euphoria" ("severe distress"); we classify years in which the summed differences are between $+/-0.75$ and $+/-1.5$ standard deviations from the mean as years of "moderate" expansion (distress); and we classify years in which the summed differences fall between -0.75 and +0.75 standard deviations from the mean as "normal."

In constructing the index, we treated the two periods, 1870-1933 and 1934-97 entirely separately. Observations in one period have no influence on the classification of years in the other period and, thus, one cannot directly compare index classifications in one period with those in the other. This is in contrast to the qualitative index described below, where we tried to be as consistent as possible over the entire 1792-1997 period. In estimating the probit model, we estimate separate coefficients for each independent variable in each subperiod. Hence, consistency in the index between the subperiods is not important. Appendix A presents additional detail on the construction of the quantitative index.

\section{Qualitative Index}

Except for short periods, continuous, consistent time series data on bank and business conditions for the period of U.S. history before 1870 are unavailable. Thus, to extend the analysis before 1870, we have constructed a second index of financial conditions from narrative sources, principally Thorp (1926). Using Thorp (1926) and other sources, mainly Annual Reports of the

1933, because of mean reversion in the inflation rate. Hence, we would be quite surprised not to find a highly negative coefficient on price or inflation shocks in a regression of the real interest rate.

5 Asymmetric information between borrowers and lenders implies that a decline in borrower net worth will increase adverse selection and agency problems inherent in credit markets (Mishkin, 1991). 
Board of Governors of the Federal Reserve System, we constructed this "qualitative" index through to 1997.

A long-time researcher for the National Bureau of Economic Research, Willard Thorp prepared annual summaries of economic and financial conditions for a number of countries. His summaries are available through 1925. By comparing Thorp's descriptions of financial conditions across years, supplemented by other historical accounts, such as Smith and Cole (1935), we place each year into one of five categories of financial conditions.

For example, 1797 is the first year we assign to the "severe distress" category. Thorp describes the year as one of "depression; panic; ... falling prices; many failures, foreign trade restricted. Money tight; little speculation; financial panic, autumn" (p. 114). For 1798, which we classify as a year of "moderate distress," Thorp writes: "Continued depression in the North with failures; ... prosperity in the South; collapse of land speculation ... money very tight" (p. 114). For 1799, which we classify as "normal," Thorp writes: "Revival. Marked improvement in Northern activity; continued prosperity, South ... money eases somewhat" (p. 114).

We classify 1824 as a year of "financial euphoria." Thorp describes this year as one of “prosperity; widespread activity; excited speculation ... bank mania; many new banks chartered ... money easy" (p. 119). For 1850, a year we classify as one of "moderate" financial expansion, Thorp writes: "money easy; revival of stock market ... influx of gold from California" (p. 125). By contrast, for 1855 Thorp writes: “money eases, but tightens, autumn; railroad securities reach low point and recover somewhat." We classify the year as "normal."

We also classify 1853 as "normal." For that year, Thorp writes: "continued activity and expansion, slackening last quarter ... very active railroad construction; extensive speculation ... money tightens severely; panics and distress in interior cities; decline in railroad stock prices" (p. 125). 1853 illustrates the difficulty of assigning some years to a single category because financial conditions can change markedly within a year. Another such year was 1929, which might be 
characterized as a boom year before the stock market crash in October, but then one of financial distress.

For the antebellum era, we also relied on narrative and quantitative information provided by Smith and Cole (1935). Smith and Cole refer to the financial distress of 1818-19 as America's "first major banking crisis," and describe how a decline in commodity prices "meant serious losses to merchants who had speculated in commodities. ... Banks with extended loans to speculators were now confronted with a demand for specie ... and the curtailment of bank loans made the position of the American merchant even more difficult" (p. 20). This description seems consistent with later financial crises in which sudden declines in commodity prices resulted in financial losses, especially for speculators who had bet on continued price increases, and the bankers who supported them. More severe price declines were associated with widespread bank and business failures and recessions.

For the post-Civil War period, our index is again based on Thorp's (1926) narrative and, where that leaves off, on summaries of financial and economic conditions in the Annual Reports of the Federal Reserve Board.

For 1926, a year we classify as "normal," the Fed reported increased loan demand to finance strong growth in business activity, but that loans on securities had declined somewhat from the year before. The report also noted that during 1926 growth in bank credit had slowed somewhat from its pace of 1925 . Finally, the report noted the high number of small, rural bank failures that occurred during the year.

The year 1927 was difficult to classify because the Fed reported that there had been numerous initial public stock offerings and rapid growth in securities market loans. On the other hand, there also were many business failures and a decline in corporate profits. We chose a middle ground and called 1927 a "normal” year.

We classify 1928 as a "euphoric" year based on record growth in bank security loans and the Fed's description of activity in securities markets as being "extraordinary." The stock market 
boom was nearing its peak. The next year, 1929, as noted above, was difficult to classify because the boom continued into the first half of the year, but the crash came in the fourth quarter.

Because of the unsettled nature of financial markets throughout the year, in addition to the crash itself, we classify 1929 as a "normal" year, again averaging financial expansion during the first half with financial distress of the second half.

The Great Depression years are among the easiest to classify. We classify 1930 and 1933 as years of "moderate distress," and 1931 and 1932 as years of "severe distress." The recovery years, 1934-37, were "normal," with the Federal Reserve reporting an "abundance of funds seeking employment," loan repayments exceeding new loans during 1934, and no evidence of "over expansion" of credit or business activity in 1935. During 1936, however, the Fed noted growth in commercial loans and new public stock offerings, rapid rise in securities prices, but "no evidence of actual excessive expansion of bank loans." The recession year 1938 was a year of "moderate distress," while 1938-39 were "normal" and 1940 was a year of financial "expansion."

War years were among the most difficult to classify. For the Civil War, we stick close to Thorp's description for the North, which generally corresponds to the North's war successes. We also relied on Thorp's descriptions for the World War I years. We classify the first four years of World War II, 1941-44, as “moderately expansionary," and 1945-47 as “euphoric." The Federal Reserve Board concluded that during 1946, "some credit extended was probably used for speculative purposes" (Annual Report, 1946, p. 2), and noted extremely rapid increases in business and household borrowing. In 1947, the boom continued with "vigorous and widespread bank credit demand" (Annual Report, 1947, p. 2). Conditions returned to "normal" in 1948 and 1949 and the Fed noted an easing of inflationary pressures.

The 1950s began with financial "euphoria" as the Fed noted that credit was "easily available" to fuel a "boom" in housing, materials and durable goods purchases. The Fed found the expansion of bank credit so "exceptional" as to justify reimposing controls on installment credit. We characterize most of the 1950s and early 1960s as "normal," however, with little 
evidence of either exceptional exuberance or distress in financial markets. By the mid-to-late 1960s, however, financial conditions were more consistently "expansionary," with the Fed characterizing 1966 as having a "too exuberant upsurge in economic activity," and finding "widespread evidence of domestic overheating" in 1968. The Fed also reported that "inflationary psychology was becoming embedded in decision making for key sectors of the economy."

With inflationary surges and retreats, financial distress emerged in the mid-1970s. For 1974, the Fed reported record mortgage interest rates and a tight credit supply. Franklin National Bank failed, the stock market was down and numerous real estate investment trusts failed. We characterize the year as one of "moderate" distress. By 1977 inflation was rising rapidly and the financial sector was booming. The Fed noted a boom in construction in 1977, along with surging credit demand, particularly by households. We characterize both 1977 and 1978 as years of “moderate" financial expansion. Expansion continued in the first half of 1979, but credit demand dropped sharply in the fourth quarter when monetary policy was abruptly tightened.

The 1980s proved difficult to categorize, particularly the middle part of the decade. The years 1980-82 included two recessions. We classify 1981 and 1982 as having had "moderate" distress. For 1981, the Fed noted a sharp increase in business failures and personal bankruptcies, and corporate bond rating downgrades. Business failures were up again in 1982, along with mortgage loan delinquencies and defaults.

"Generally stable conditions [prevailed] in financial markets" during 1983, according to the Fed, and we classify the year as a "normal" one. The years 1984-86 were highly mixed, however. In 1985 "stock prices rose substantially" and "debt growth was strong," according to the Fed, but bank and S\&L failures increased. Personal bankruptcies and corporate bond defaults rose in 1986, and real interest rates remained high throughout the period.

1987 was also a year of "moderate" distress, with the stock market crash in October, sharply lower banking system profits, as well as numerous bank and S\&L failures. The years 1988-89 were back to "normal," followed by two years (1990-91) of "moderate" distress 
characterized by regional banking problems, tighter lending standards and some stress on finance companies and insurance firms. We classify the next four years, 1992-95, as "normal," but 199697 as "expansionary" because of the booming stock market and increased borrowing by households and firms.

Comparing the Indexes

Figures 1-5 plot each index against price level (inflation) shocks. Index categories are ordered from 1 ("severe distress") to 5 (financial "euphoria"), with 3 assigned to "normal" years. For 1795-1869, we have only the qualitative index based on narrative sources. By comparison with later years, during 1795-1869, price level shocks were large, and the index also varies considerably from year to year. Moderate or severe financial distress occurred in several years that had deflationary shocks. On the other hand, deflationary shocks also occurred in a few years, e.g., 1823-24, in which our narrative sources indicate that financial conditions were strong. Moreover, a few years of moderate or severe financial distress, e.g., 1819, 1837 and 1857, were not characterized by large deflationary shocks. Our narrative sources place a great deal of emphasis on financial panics, which often occurred at the beginning of major declines in prices. Our concern here, however, is not with the causes of financial panics, but with financial distress characterized by bank and other commercial failures and losses. These tended to occur during the deflationary periods that followed panics but, unfortunately, we lack consistent annual time series data on such measures of financial conditions for this period.

We do have reasonably good data on measures of financial conditions after the Civil War, which we use to construct our quantitative index for 1870-1997. Figure 2 plots this index against price level shocks for 1870-1933. Price level shocks are plotted on the same scale as in Figure 1, and it is readily apparent that price shocks were considerably smaller on average in the later period. Only the deflationary shock of 1921 rivals the worst shocks of 1795-1869. Nevertheless, considerable financial distress was associated with deflation during the 1870 s and during 1930-33. Financial euphoria, characterized by unusually low business and bank failure 
rates, and low real interest rates and quality spreads, occurred during the highly inflationary years of World War I (1916-18).

Figure 3 plots the qualitative index and price level shocks during 1870-1933. The qualitative index has more variation in this period than does the quantitative index. Generally, this reflects the emphasis placed on financial panics by our narrative sources. However, the first substantial difference between the two indexes occurs in 1878, which is classified as "normal" by the qualitative index, but as "severe distress" by the quantitative index. Thorp (1926) describes the year as one of "revival," with "money very easy; stocks dull with temporary revival," and with an advance of bond prices. Comparison of Thorp's description for 1878 with those for other years led us to classify the year as "normal." 1878 , however, had the highest rate of business failures of any year between 1870 and 1933, and the other distress variables were moderately high. Hence, in the quantitative index, the year ranks as among the most severely distressed. By contrast, the qualitative index classifies 1893-96 as years of moderate or severe financial distress, whereas the quantitative index classifies them as closer to "normal." A severe banking panic occurred in 1893 and Thorp (1926) describes financial conditions in 1893 as a "gradual decline to extreme depression; money very tight ... violent panic.” Both bank and business failure rates were high in 1893 , but the real interest rate and quality spread were near their period medians. Hence, the quantitative index classifies the years as having just "moderate distress." Business failures remained high in 1894-96, but bank failures fell off, while the real interest rate and quality spread remained normal. The quantitative index thus classifies 1894-96 as "normal." Thorp, by contrast, describes 1894 as having a "deep depression ... many failures." 1895 was a year of "dullness ... continued numerous failures," and 1896 saw a "return to state of intense depression ... large increase in failures." We cannot say whether Thorp's characterization of the period is more or less accurate than suggested by the quantitative series we examine. But, by using both indexes, we learn something about how robust our estimates of the impact of aggregate price shocks on financial conditions are. 
Figures 4 and 5 plot the two indexes against inflation rate shocks for 1934-97. The later years of World War II and the immediate postwar years were the most financially expansive or euphoric in both indexes. Most of the 1950s-70s are in the "normal" category, though four years in the late 1960s and 1977-78 were "moderately expansive" according to the qualitative index. Both indexes identify the early 1980s as years of financial distress, but the quantitative index more frequently classifies years as having "moderate" or "severe" distress. The 1980s had the highest rates of bank loan charge-offs and business failures since the Great Depression, alongside unusually high real interest rates and quality spreads - hence the "severe" classification by the quantitative index. The Fed's Annual Reports, however, noted that many of these years witnessed strong advances in the stock market, and considerable merger and acquisition activity. Thus, from the narrative, the 1980s generally sound less severely distressed than is suggested by the four quantitative series. Again, our interest is not in determining which index best characterizes financial conditions. While there are differences between them, for most years the indexes are consistent with one another. Whether the differences are important will be revealed by our econometric analysis below.

\section{DYNAMIC ORDERED PROBIT MODEL OF FINANCIAL CONDITIONS INDEX}

To estimate the impact of aggregate price shocks on our indexes of financial conditions, we use a probit model modified to account for the time series features of the data. In particular, the dynamic ordered probit model is designed for discretely-valued time-series data in which pressure for a discrete change can build across time. Here we apply data-augmentation techniques that make estimation of a dynamic probit much simpler than the approximate maximum-likelihood procedure of Eichengreen, et. al. (1985). The numerical integration outlined in Eichengreen, et. al. (1985) undoubtedly prevented the dynamic ordered probit model from seeing more widespread use, despite the fact that probit models are often applied to time series, where serial correlation is likely to be an important feature of the data. 
The general set-up is that an observed variable, $y$, takes on one of $J$ different discrete values. A continuous latent level, $y^{*}$, follows a standard time series process and determines the discrete level of $y$. The mapping between the continuous latent variable and the discrete variable is

$$
y_{t} \in \text { category } j \text { if } y_{t}^{*} \in\left(c_{j-1}, c_{j}\right) \text {, }
$$

where $c$ is a vector of cut-off parameters that determine the boundaries of the categories.

A basic time-series probit model of $y^{*}$ includes at least one autoregressive term on the right-hand side of the equation for the latent variable:

$$
y_{t}^{*}=\rho y_{t-1}^{*}+\mathrm{X}_{t-1} \beta+\varepsilon_{t}
$$

The dynamic ordered probit model of Eichengreen, et. al. (1985) serves as a time-series probit because it allows the continuous latent variable to move gradually toward the boundary with another category over several periods. The maximum-likelihood estimation procedure of Eichengreen et. al. (1985) requires numerical evaluation of an integral for each observation in order to obtain the density, $h$, of $y_{t}^{*}$, where $\phi$ is the standard normal density and $I_{t}$ is the information available up to time $t$ :

$$
h\left(y_{t}^{*} \mid I_{t}\right)=1 / \sigma_{\varepsilon} \int_{l_{t-1}}^{U_{t-1}} \phi\left(y_{t}^{*} \mid \sigma_{\varepsilon}\right) h\left(y_{t-1}^{*} \mid I_{t}\right) d y_{t-1}^{*},
$$

where $\left\{l_{t}, U_{t}\right\}=\left\{c_{j-1}, c_{j}\right\}$ if $y_{t} \in$ cat. $j$. Because numerical evaluation of these integrals is time-consuming and approximate, it is not tractable under direct maximum-likelihood estimation to extend the model to include additional features, such as regime-switching parameters.

In cases like the dynamic probit, where the joint density of $y_{t}^{*}$ and $y_{t-1}^{*}$ is difficult to evaluate, data augmentation via Gibbs sampling offers a tractable method to generate a sample of draws from a joint distribution through a sequence of draws from the respective conditional distributions. Data augmentation in the present context allows one to treat augmented values of 
$y_{s}^{*}, s \neq t$, as observed data when evaluating the conditional density of $y_{t}^{*}$. Thus, one conditions

the density of $y_{t}^{*}$ on a value, instead of a density, of $y_{t-1}^{*}$, making the problem much simpler than recursive evaluation of the above integral. Furthermore, once the latent variable has been augmented, it becomes straightforward to model any regime switching, such as conditional heteroscedasticity. Appendix B contains details of the regime switching and the Gibbs sampling framework as applied to the dynamic ordered probit.

\section{Explanatory Variables}

We use the unanticipated components of the price level and inflation described above to estimate the effects of aggregate price shocks on financial conditions. We control for the possible impacts of both real and liquidity shocks on financial conditions. All data are annual and, except for a lagged dependent variable, contemporaneously timed. The specific variables we use and data sources are described in Appendix A.

Real output shocks (e.g., a crop failure) likely increase financial distress. We control for real output fluctuations using available data on GNP and the business cycle phase. We expect that negative shocks to GNP growth would increase financial distress. Similarly, we expect greater distress during business recessions than during expansions. ${ }^{6}$

Over time, nominal money supply shocks will affect inflation. In the short run, however, liquidity shocks might contribute to financial distress independent of their impact on the price level or inflation. Hence, we include monetary base growth as an independent variable. We expect that declines in base growth, for example, will increase financial distress.

\section{Dynamic Probit Model Results}

As in Figures 1-5, we assign values to the index categories of financial conditions listed in Table 1, from 1 for "severe distress" to 5 for financial "euphoria." Hence, in the ordered probit

\footnotetext{
6 Initially, we also included changes in the terms of trade as an independent variable. In no case did we estimate that changes in the terms of trade had a significant effect on financial conditions and, hence, we omitted that variable from further consideration.
} 
model, a positive coefficient on an independent variable would indicate that an incremental increase in the value of that variable would lower financial distress or, equivalently, encourage financial expansion or euphoria. We expect to find positive coefficients on the price level and inflation shock variables, indicating, for example, that an unanticipated decline in the price level increases financial distress.

Table 2 reports coefficient estimates and both 95 and 90 percent confidence intervals for alternative specifications of the dynamic probit analysis. To produce reliable estimates of the cutoff parameters - which provide an indication of how much the values of the independent variables must change to move from one category of financial distress to another - we need reasonably large numbers of observations in each category. Hence, we estimated the models over the entire 1792-1997 period, allowing for the coefficients on the independent variables to differ between subperiods. Confidence intervals reported in Table 2 reflect the ranges over which the coefficients fall in 95 (or 90) percent of the chained draws from the Gibbs sampling estimation described above and in Appendix B.

All specifications reported in Table 2 include anticipated changes in the price level $(\mathrm{E}(\Delta \ln \mathrm{P}))$ and price level shocks $\left(\mathrm{P}^{\mathrm{ue}}\right)$ for $1792-1869$ and for $1870-1933$, and anticipated changes in the inflation rate $(\mathrm{E}(\Delta \pi))$ and inflation rate shocks $\left(\pi^{\mathrm{ue}}\right)$ for 1934-97. Doing so tests our conjecture that only aggregate price shocks should affect financial conditions as we expect not to obtain the same (or significant) coefficients on anticipated movements in the aggregate price level. $^{7}$

We investigate whether the impact of price level shocks differed between 1792-1869 and 1870-1933 because the price level appears to have been more stable after the Civil War, and because 1870 marks the beginning of our quantitative index of financial conditions. Each

\footnotetext{
7 Because we break the aggregate price level (inflation rate) into anticipated movements and shocks, our econometric model includes generated regressors. No adjustment of the standard errors is required, however, for either the shock variables or for the anticipated price (inflation) variables since for the latter we are interested only in the null hypothesis that they have zero coefficients.
} 
specification also includes annual percent changes in U.S. gross national product ( $\Delta \ln \mathrm{GNP})$. We allow the coefficient on GNP growth to change in 1874 because of a break in data sources. An increase in GNP growth might be expected to lessen financial distress. Hence, we expect a positive coefficient on this variable. ${ }^{8}$

We also include growth of the monetary base $(\Delta \ln$ Base $)$ as an independent variable. As with GNP, we permit the coefficient on this variable to differ across periods that reflect our use of different data sources. We expect that positive growth in the monetary base would reduce financial distress, and hence we expect a positive coefficient on this variable.

Each specification reported in Table 2 is estimated using our "qualitative" index and our "quantitative" index of financial conditions separately as dependent variables. Because the quantitative index does not begin until 1870, the qualitative index is spliced to it for the period 1792-1869. Each specification is also estimated once with and once without dummy variables for war (and immediate postwar) years to control for possible differences in the behavior of financial conditions during wartime. ${ }^{9}$

The results reported in Table 2 support the hypothesis that, during 1792-1933, shocks to the price level affected financial conditions (aggregate price shock variables are in boldface). The positive coefficients on the price level shock variables for 1792-1869 and 1870-1933 indicate that deflationary price level shocks worsened financial distress (or, equivalently, that positive price level shocks lessened financial distress). For 1792-1869, the coefficients are statistically different from zero at 95 percent if wartime dummies are included and at 90 percent if they are not included. ${ }^{10}$ However, a rather large price level shock is required to move the index from its

\footnotetext{
${ }^{8}$ In an alternative specification, we replaced GNP growth with a dummy variable taking the value " 1 " in years of business recession (contraction years as determined by NBER reference cycle dates) and the value " 0 " in nonrecession years (expansion years). Our results were not qualitatively different from those reported here.

9 The following years were treated as war (and post-war) years, and thus were assigned dummy variables: 1813-15, 1861-67, 1917-21, and 1942-49.

${ }^{10}$ We also estimated regressions in which the coefficients on positive and negative price level shocks were allowed to differ. For 1792-1869, we reject at the 95 percent level of significance the hypothesis that the coefficients are equal. Only the coefficient on positive price shocks is statistically significant. For 1870-1933 and 1934-97, however, we do not reject the hypothesis of symmetric effects. Further, a Wald test for symmetry
} 
unconditional mean, which falls in the "normal" category of financial conditions, to the "moderate distress" category. For the qualitative index, a 2.03 standard deviation-sized shock is required for the model that includes war dummies, and a 2.29 standard deviation-sized shock is required for the model that does not include war dummies. For the quantitative index, the comparable shocks are 2.18 standard deviations and 2.59 standard deviations. ${ }^{11}$

For 1870-1933, the coefficient on price shocks is significant at 95 percent regardless of whether or not wartime dummies are included when the quantitative index is used as the dependent variable. When the qualitative index is used, the coefficient is significant at 90 percent, but only if wartime dummies are included. Compared to the previous period, somewhat smaller deflationary shocks are required to cause moderate financial distress. Using the quantitative index, a 1.15 standard deviation-sized shock is required for the model that includes war dummies, and a 1.24 standard deviation-sized shock is required for the model that does not include war dummies. For the qualitative index, the comparable shocks are 1.58 standard deviations and 1.67 standard deviations.

For 1792-1869, we cannot reject the hypothesis that the coefficient on anticipated price level movements is zero in any of the specifications. For 1870-1933, we cannot reject the hypothesis for either specification using the quantitative index. We estimate positive coefficients for GNP growth in both periods. For 1875-1933, the coefficient is significant at 90 percent or better for both indexes, indicating that increases in GNP growth lessened financial distress or, equivalently, contributed to financial expansion. Generally, we find little evidence that monetary base growth affected financial conditions, apart from any impact it might have had through real output or the price level.

across all three time periods jointly does not reject, so we did not report results for models with asymmetric response to positive and negative price shocks. The separate estimates are available upon request.

11 Although only the qualitative index was constructed for this period, we get slightly different estimates for 1792-1869 when the qualitative index is spliced to the quantitative index for 1870-1997 (the "quantitative index" results) than when the qualitative index is used throughout. This occurs because the breaks in the monetary base and GNP series occur in different years than those for the index, and because the cut-off and Markov switching parameters are estimated over the entire sample period. 
For the post-1933 period, the coefficients on inflation shocks are positive, indicating that a disinflationary shock, for example, increased financial distress. The coefficients are statistically significant only during 1980-97, however, and then only when financial conditions are measured with the quantitative index. Using the quantitative index, for 1980-97, we find that a 1.01 standard deviation-sized disinflationary shock is required to move financial conditions from the unconditional mean of the index (which is in the "normal" category) to "moderate distress" if war dummies are included in the model, and that a 1.06 standard deviation-sized shock is required if war dummies are not included.

\section{Estimation for Individual Time Series}

For additional insight into the impact of aggregate price shocks on financial conditions historically, we estimated separate OLS regressions for each of the four series used to construct the quantitative index. Doing so provides an indication of whether the individual series underlying the quantitative index are themselves associated with aggregate price shocks. In addition, because interest rate data are available before the Civil War, we can estimate models for some of the individual series over longer periods than we can for the index.

Table 3 reports regression estimates for the period ending in 1933 (1932 in the case of the bank failure rate). ${ }^{12}$ The table indicates the estimation period, dictated by the availability of data, for each dependent variable. All data are annual. The specifications reported do not include dummy variables for the Civil War and World War I years (and the immediate postwar years). Except as noted below, estimation results for specifications that do include these dummies are not qualitatively different from those reported in Table 3.

We find support for the hypothesis that price level disturbances affect financial conditions in the behavior of the business failure rate. For 1870-1933, unanticipated movements in the price level have a negative and statistically significant impact on the business failure rate -

\footnotetext{
12 The Bank Holiday, and subsequent government licensing procedures for re-opening banks, makes the computation of a bank failure rate for 1933 on a basis that is consistent with other years impossible.
} 
deflation, for example, caused the rate of business failures to rise. ${ }^{13}$ The estimated coefficients on GNP and monetary base growth are also statistically significant, and indicate that declines in GNP and money growth increased the business failure rate.

We find no direct evidence that price level shocks affected bank failure rates during 1865-1932. ${ }^{14}$ As with the business failure rate, however, we find that unanticipated deflation worsened financial distress as measured by the real interest rate and quality spread. ${ }^{15}$ For the quality spread, we reject the hypothesis that negative and positive price level shocks had similarsized effects on the dependent variable. We find that negative surprises tended to increase the quality spread, while positive surprises had no statistically significant effect. For the real interest rate, business failure rate, and bank failure rate, we were unable to reject the equality of the coefficients on positive and negative inflation shocks and, hence, do not report them separately. ${ }^{16}$

Table 4 reports similar regressions for 1934-97. The regressions are estimated for the first-difference of each dependent variable because of persistence in the levels of the series.

We estimate a statistically significant impact of inflation shocks on changes in the business failure rate for 1934-97, after controlling for money supply and real GDP growth. Unexpected disinflation, for example, increased the business failure rate. ${ }^{17}$ Not surprisingly, we find that real output growth had strong, negative impacts on the business failure rate.

We find some evidence that inflation shocks affected the bank failure rate and real interest rate during 1934-97. But, because there were few bank failures before 1980 (in no year

\footnotetext{
13 When dummy variables are included for the years 1917-21, the years of large inflation and deflation associated with World War I, the coefficient on price level shocks is somewhat smaller and significant at only 83 percent.

${ }_{14}$ Our results contrast with those of Weber (1986) who, using Granger-causality analysis, finds a statistically significant impact of price shocks on the bank failure rate in this period.

15 The quality spread regressions also include a dummy variable to account for a change in the series' measure in 1919. See Appendix A for details.

16 The real interest rate and quality spread measures exhibit some persistence in levels. However, if dummy variables for the years 1917-21 are included, the regression errors exhibit little evidence of first-order autocorrelation and the model coefficients are not substantively affected.

17 The coefficient on inflation shocks is, however, statistically significant only when dummy variables for the World War II years - 1942-45 - are included in the model. We also investigated whether negative inflation shocks had a greater-sized impact than positive shocks, and whether inflation shocks had a different impact after 1980 than before. In neither case could we reject the hypothesis of equal-sized impacts.
} 
between 1945 and 1980 was there more than 10 failures out of a population of some 20,000 banks) and, hence, little variability in the data to explain, we were unable to estimate a sensible regression for the bank failure rate. ${ }^{18}$

\section{CONCLUSION}

Our investigation of financial instability, as reflected by either single variable measures or indexes of financial conditions, generally supports the hypothesis that financial instability is exacerbated by unanticipated movements in the price level or inflation rate. Negative aggregate price shocks tend to worsen financial distress, while positive price shocks tend to encourage financial expansion.

Our evidence for the impact of price level shocks is strongest for the period 1870-1933, during most of which the United States was anchored to the gold standard. Because of this anchor, the price level was expected to change little over the long run, with price level declines expected to follow increases of similar magnitude. Indeed, except during World War I, the price level changed little between 1870 and 1929 in comparison with either the antebellum or postWorld War II periods. Serious financial distress accompanied severe deflation during the Great Depression of 1930-33, however, paving the way for fundamental reforms to protect the financial system from macroeconomic shocks while partially insulating the U.S. money stock from gold shocks.

For 1934-97, we find that inflation shocks had a statistically significant impact on financial conditions, as reflected in business failures. Our results suggest, however, that aggregate price shocks did not have as strong an impact on financial conditions after 1933 as price level shocks had in the years before. The different response across regimes might reflect New Deal institutional changes, including construction of a safety net for the financial sector,

\footnotetext{
${ }^{18}$ We found no statistically significant differences in the coefficients on positive and negative inflation shocks for any of the dependent variables. We did, however, find that for the real interest rate and quality spread, the coefficients on inflation shocks are not stable across the 1934-79 and 1980-97 subperiods. For the quality spread, the coefficient for 1934-79 is negative, while the coefficient for 1980-97 is positive. Neither, however, is
} 
especially for the banking system, and reorganization of the Federal Reserve into an effective lender of last resort. Under the new regime, financial response to macroeconomic shocks, including inflation shocks, appears to have been slower and perhaps less severe than it had been to similar shocks before 1934 .

Environmental changes in the late 1970s and 1980s made the banking system more vulnerable to macroeconomic shocks, even though key features of the safety net, such as deposit insurance and "too big to fail" closure policies, remained in place and partly insulated and certainly delayed the impact of disinflation on financial intermediaries. Considerable financial instability accompanied high inflation during the 1970s and, especially, sharp disinflation during the 1980s. The dynamic probit model estimates for our quantitative index indicate that financial conditions were more affected by inflation shocks during the 1980s than they had been during 1934-79. These results suggest the need for further research to investigate the specific channels by which macroeconomic shocks and environmental changes interacted to increase financial stresses. Despite the influence of regulation and other institutional factors at various times, however, our results indicate that a monetary regime that produces aggregate price stability will, as a byproduct, tend to promote stability of the financial system.

significantly different from zero at conventional levels. For the real interest rate, the coefficient on inflation shocks falls from -0.92 to -0.39 between the two subperiods, and the difference is statistically significant. 


\section{References}

Albert, J. H., and Chib, S., "Bayesian Analysis of Binary and Polychotomous Response Data," Journal of the American Statistical Association 88 (1993), p. 669-79.

Barsky, Robert B., "The Fisher Hypothesis and the Forecastability and Persistence of Inflation," Journal of Monetary Economics (January 1987), pp. 3-24.

Berry, Thomas Senior, "Production and Population Since 1789: Revised GNP Series in Constant Dollars," Bostwick Paper No. 6, 1988.

Bordo, Michael D. and Schwartz, Anna J., "Monetary Policy Regimes and Economic Performance: The Historical Record," Handbook of Macroeconomics. North Holland, 1999.

Calomiris, Charles W. and Wheelock, David C., "Was the Great Depression a Watershed for American Monetary Policy?," in M. Bordo, C. Goldin, and E. White, eds. The Defining Moment: The Great Depression and the American Economy in the Twentieth Century. Chicago: University of Chicago Press, 1998, pp. 23-66.

Chib, S., "Calculating Posterior Distributions and Modal Estimates in Markov Mixture Models," Journal of Econometrics 75 (1996), pp. 79-97.

David, Paul A. and Solar, Peter, "A Bicentenary Contribution to the History of the Cost of Living in America," Research in Economic History (1977), pp. 1-80.

Dueker, Michael J., "Conditional Heteroscedasticity in Qualitative Response Models of Time Series: A Gibbs Sampling Approach to the Bank Prime Rate," Journal of Business and Economic Statistics 17 (October 1999), pp. 466-72.

Dwyer, Gerald P. and Gilbert, R. Alton, "Bank Runs and Private Remedies," Federal Reserve Bank of St. Louis Review (May/June 1989), pp.43-61.

Eichengreen, Barry, Watson, Mark W., and Grossman, Richard S., "Bank Rate Policy Under the Interwar Gold Standard," Economic Journal 95 (1985), pp. 725-45.

Fisher, Irving, "The Debt Deflation Theory of Great Depressions," Econometrica (1933), pp. 337-57.

. Booms and Depressions. New York: Adelphi, 1932.

Friedman, Milton and Schwartz, Anna J. Monetary Statistics of the United States: Estimates, Sources, and Methods. New York: Columbia University Press, 1970.

and . A Monetary History of the United States, 1867-1960. Princeton: Princeton

University Press, 1963.

Gelfand, A. E., and Smith, A. F. M., "Sampling-Based Approaches to Calculating Marginal Densities," Journal of the American Statistical Association 85 (1990), pp. 398-409.

Gordon, Robert J. Macroeconomics. Glenview, IL: Scott, Foresman/Little Brown, 1990. 
Homer, Sidney and Sylla, Richard E. A History of Interest Rates. New Brunswick: Rutgers University Press, 1996.

Lucas Jr., Robert E., "Some International Evidence on Output-Inflation Tradeoffs," American Economic Review (June 1973), pp. 326-34.

, "Expectations and the Neutrality of Money," Journal of Economic Theory (April 1972), pp. 103-24.

Macaulay, Frederick. Some Theoretical Problems Suggested by the Movement of Interest Rates, Bond Yields and Stock Prices in the United States Since 1859. New York, National Bureau of Economic Research, 1938.

Mishkin, Frederic S., "Asymmetric Information and Financial Crises: A Historical Perspective," in R. Glenn Hubbard, ed. Financial Markets and Financial Crises. Chicago: University of Chicago Press, 1991, pp. 69-108.

Schwartz, Anna J., "Comment on 'Debt-Deflation and Financial Instability: Two Historical Explorations' by Barry Eichengreen and Richard S. Grossman," in Forrest Capie and Geoffrey E. Wood, eds., Asset Prices and the Real Economy. New York: St. Martins Press, 1997, pp. 100-105.

, "Why Financial Stability Depends on Price Stability," Economic Affairs (Autumn 1995), pp. 21-25.

, "Financial Stability and the Federal Safety Net," in William S. Haraf and Rose Marie Kushneider, eds., Restructuring Banking and Financial Services in America. Washington, D. C.: American Enterprise Institute, 1988, pp. 34-62.

Smith, Walter B. and Cole, Arthur Harrison. Fluctuations in American Business, 1790-1860. Cambridge: Harvard University Press, 1935.

Thorp, Willard Long. Business Annals. New York: National Bureau of Economic Research, 1926.

Weber, Ernst Juerg," The Causes of Bank Failures: Deflationary Spells," Economics Letters 20 (1986), pp. 359-62.

White, Eugene N. The Regulation and Reform of the American Banking System, 1900-1929. Princeton: Princeton University Press, 1983. 


\section{Appendix A: Data Sources and Definitions}

Bank Failure Rate: Number of Banks, 1865-96, White (1983, Table 1.1); 1896-1997, Federal Reserve Board, Banking and Monetary Statistics and Annual Statistical Digest (various years). Number of Failures, 1865-91, FDIC Annual Report (1934, p. 92); 1892-1933, Federal Reserve Board, Banking and Monetary Statistics (1943, p. 283); 1934-97, FDIC.

Bank Loan Charge-off Rate: Net loan charge-offs at commercial banks divided by total commercial bank assets, 1934-97, FDIC.

Business Cycle Reference Dates: 1790-1854, Economic Cycle Research Institute web site, www.businesscycle.com; 1854-1997, National Bureau of Economic Research web site, www.nber.org.

Business Failure Rate: 1870-1970, Historical Statistics of the United States (1976, Series V-23); 1971-97, Economic Report of the President (1999, Table B-96).

Gross National Product: 1789-1874, Berry (1988); 1875-1959, Gordon (1990); 1959-97, U.S. Department of Commerce.

Monetary Base: 1790-1866, Friedman and Schwartz (1970); 1867-1935, Friedman and Schwartz (1963, Table B-3); 1936-97, Federal Reserve Bank of St. Louis, adjusted monetary base.

Price Level: 1789-1947, David and Solar (1977); 1948-97, Bureau of Labor Statistics CPI measure.

Real Interest Rate (Commercial Paper Rate minus current year's inflation rate): Commercial Paper Rate: 1831-1900, Homer and Sylla (1996, Table 44); 1901-97, Federal Reserve Board.

Quality Spread: 1857-1918, spread between low and high quality railroad bond yields from Macaulay (1938, pp. aa34-aa90) (3 lowest and 3 highest bonds, 1857-66; 5 lowest and 5 highest bonds, 1867-81; 8 lowest and 8 highest, 1882-1887; 10 lowest and 10 highest, 1888-1918); 191997, spread between average yield on Moody's Baa-rated corporate bonds and U.S. long-term Treasury composite bond, Federal Reserve Board. 


\section{Appendix A, continued}

\section{Construction of Quantitative Index of Financial Conditions}

The index is derived from four series for each subperiod. For 1870-1933, these series are the bank failure rate (except for 1933), the business failure rate, the real interest rate and the quality spread. For 1934-1997, the series are the bank loan charge-off rate, the business failure rate, the real interest rate and the quality spread.

For each variable in each subperiod, we compute the distances between each observation and the subperiod median for that variable. We measure distances from the median, rather than mean, because the distributions of the variables tend to be skewed. Because of skewness, we also evaluate the distances for observations that are below the median separately from those above the median. Distances for those observations that are below the median are divided by the standard deviation of a series consisting of all observations below the median and an equal number of generated observations of equal distances above the median. Similarly, distances for observations that are above the median are divided by the standard deviation of a series consisting of all observations above the median and an equal number of generated observations of equal distance below the median. The generated observations are then discarded, leaving a series of observations for each variable consisting of standardized distances from the median.

For each year, we compute a simple unweighted average $\left(\mathrm{Z}_{\mathrm{t}}\right)$ of these standardized distances across the four variables. Next, we compute an overall subperiod mean and standard deviation of these average distances. $\mathrm{Z}_{\mathrm{t}}$ larger than 1.5 standard deviations above the subperiod mean are assigned to the "severe distress" category; $Z_{t}$ larger than 0.75 standard deviations above the subperiod mean are assigned to the "moderate distress" category; $Z_{t}$ falling between $+/-0.75$ standard deviations of the mean are assigned to the "normal" category; $Z_{t}$ between -0.75 and -1.5 standard deviations of the mean are in the "moderate expansion" category; and Zt below -1.5 standard deviations of the mean are in the "euphoria" category.

\section{Expected/Unexpected Aggregate Price Decomposition}

We use a trend/cycle decomposition of inflation as the basis for our calculation of the inflation/price level explanatory variables. The following unobserved-components model is estimated via the Kalman filter:

$$
\begin{aligned}
& y_{t}=y_{1 t}+y_{2 t} \\
\text { Trend: } & y_{1 t}=\mu+y_{1, t-1}+n_{t}, \\
\text { Cycle: } \quad y_{2 t}= & \phi_{1} y_{2, t-1}+\phi_{2} y_{2, t-2}+e_{t}, \\
\text { variance parameters : } & \sigma_{n}^{2}, \sigma_{e}^{2}, \sigma_{n, e}
\end{aligned}
$$

The expected price level (inflation rate) is then

$$
y_{1, t-1}+\mu+\phi_{1} y_{2, t-1}+\phi_{2} y_{2, t-2} \text {. }
$$




\section{Appendix B: The Dynamic Ordered Probit Model in Detail}

\section{Markov regime switching}

We include two forms of regime switching in the latent variable for the time-series probit. First, the model allows for heteroscedasticity by way of Markov-switching variances. The explanatory variables and the data that went into the construction of the quantitative index both contain outliers that should be downweighted when estimating the regression coefficients. Therefore we introduce switching between a high and low variance level governed by a binary variable, $S 1$ :

$$
\sigma_{S 1_{t}}^{2} \in\left\{\sigma_{0}^{2}, \sigma_{1}^{2}\right\}
$$

Second, the model includes Markov switching in the intercept, $\beta_{0}$, to allow for shifts in the unconditional level of the financial conditions index. The binary variable that governs drift switching is $S 2$ :

$$
\begin{aligned}
& y_{t}^{*}=\rho y_{t-1}^{*}+\beta_{0}\left(S 2_{t}\right)+\mathrm{X}_{t-1}^{\prime} \beta+\sigma_{S 1_{t}} e_{t} \\
& \beta_{0}\left(S 2_{t}\right) \in\left\{\beta_{01}, \beta_{0 h}\right\} \\
& e_{t} \text { is } N(0,1) \\
& \varepsilon_{t}=\sigma_{S 1_{t}} e_{t}
\end{aligned}
$$

The transition probabilities for the state variables, $S 1$ and $S 2$, are:

$$
\begin{aligned}
& \operatorname{Prob}\left(S 1_{t}=0 \mid S 1_{t-1}=0\right)=p_{1} \\
& \operatorname{Prob}\left(S 1_{t}=1 \mid S 1_{t-1}=1\right)=q_{1} \\
& \operatorname{Prob}\left(S 2_{t}=0 \mid S 2_{t-1}=0\right)=p_{2} \\
& \operatorname{Prob}\left(S 2_{t}=1 \mid S 2_{t-1}=1\right)=q_{2} .
\end{aligned}
$$

The Gibbs sampler and conditional distributions

The Gibbs sampler is an attractive estimation procedure for the time-series probit because the conditional distribution of the latent variable is easy to derive, given the other parameters and 
state variables $\left(\beta, \rho, S 1, S 2, p_{j}, q_{j}\right), j=1,2$, and the conditional distributions of the state variables are simple, given values for the latent variable and parameters. The key idea behind Gibbs sampling is that after a sufficient number of iterations, the draws from the respective conditional distributions jointly represent a draw from the joint posterior distribution, which often cannot be evaluated directly (Gelfand and Smith, 1990).

Gibbs sampling consists of iterating through cycles of draws of parameter values from conditional distributions as follows:

$$
\begin{array}{l|l}
f\left(\varsigma_{1}^{(i+1}\right. & \left.\varsigma_{2}^{(i)}, \varsigma_{3}^{(i)}, \varsigma_{4}^{(i)}, \mathrm{Y}_{T}\right) \\
f\left(\varsigma_{2}^{(i+1}\right. & \left.\varsigma_{1}^{(i+1)}, \varsigma_{3}^{(i)}, \varsigma_{4}^{(i)}, \mathrm{Y}_{T}\right) \\
f\left(\varsigma_{3}^{(i+1}\right. & \left.\varsigma_{1}^{(i+1)}, \varsigma_{2}^{(i+1)}, \varsigma_{4}^{(i)}, \mathrm{Y}_{Y}\right) \\
f\left(\varsigma_{4}^{(i+1}\right. & \left.\varsigma_{1}^{(i+1)}, \varsigma_{2}^{(i+1)}, \varsigma_{3}^{(i+1)}, \mathrm{Y}_{T}\right)
\end{array}
$$

where $\mathrm{Y}_{T}$ stands for the entire history of the data and superscript $i$ indicates run number $i$ through the Gibbs sampler. At each step, a value of $\zeta$ is drawn from its conditional distribution. As discussed in Albert and Chib (1993), all of the necessary conditional distributions can be standard statistical distributions, given appropriate choices for prior distributions.

The Gibbs sampler was run for a total of 8000 iterations in each estimation. The first 3000 iterations were discarded to allow the sampler to converge to the posterior distribution. For this application, parameters and latent data are sampled in the following groups:

$$
\begin{aligned}
& \varsigma_{1}=\left\{y_{t}^{*}\right\}, t=1, \ldots, \mathrm{T} \quad \text { latent variables } \\
& \varsigma_{2}=\left(\left\{S 1_{t}\right\},\left\{S 2_{t}\right\}\right), t=1, . ., \mathrm{T} \text { states } \\
& \varsigma_{3}=(\beta, \rho) \quad \text { regression coefficients } \\
& \varsigma_{4}=\left(p_{j}, q_{j}\right), j=1,2 \text { transition probs. }
\end{aligned}
$$


Several of the parameters regarding the Markov switching were drawn in accordance with the procedures from Dueker (1999). In all cases the Markov state variables, $S 1$ and $S 2$, were treated symmetrically, so in the following description we drop references to a particular state variable.

\section{Priors and posteriors for transition probabilities}

The likelihood function for a discrete binary random variable that is governed by a firstorder Markov process is

$$
L(p, q)=p^{n 00}(1-p)^{n 01} q^{n 11}(1-q)^{n 10}
$$

where $n_{i j}$ is the number of transitions between $S_{t-1}=i$ and $S_{t}=j$.

The prior is to assign parameters $u_{i j}$, where the ratio between $u_{00}$ and $u_{01}$, for example, represents a prior guess for the ratio between the corresponding numbers of actual transitions, $n_{00} / n_{01}$. The magnitudes of the $u_{i j}$ relative to the sample size indicate the strength of the prior. As a weak prior, we set $u_{00}=4, u_{01}=1, u_{10}=1$, and $u_{11}=4$, such that the sum of the $u_{i j}$ is low relative to the sample size.

The beta distribution is conjugate to itself, so the posterior is also beta and is the product of the prior and the likelihood of the observed transitions, so that we may draw transition probabilities from

$$
\begin{array}{l|l}
p & \tilde{S}_{T} \sim \operatorname{beta}\left(u_{00}+n_{00}, u_{01}+n_{01}\right) \\
q & \tilde{S}_{T} \sim \operatorname{beta}\left(u_{11}+n_{11}, u_{10}+n_{10}\right),
\end{array}
$$

where $\tilde{S}_{T}=\left\{S_{t}\right\}, t=1, \ldots, \mathrm{T}$. The initial values for $p$ and $q$ at the start of the Gibbs sampling were $p=0.8$ and $q=0.6$.

Priors and posteriors for Markov state variables 
We wish to sample the states in reverse order from the following probability, where $T$ stands for the entire history of the observed and latent data and $v_{t}$ is the observed and latent data at a point in time:

$$
P\left(S_{t}=0 \mid S_{t+1}, \ldots, S_{T}, Y_{T}\right)
$$

By Bayes theorem, and as outlined in Chib (1996),

$$
\begin{aligned}
P\left(S_{t}=0 \mid S_{t+1}, \ldots, S_{T},{ }_{T}\right) \propto & f\left(v_{t+1}, \ldots, v_{T}, S_{t+1}, \ldots, S_{T} \mid v_{1}, \ldots, v_{t}, S_{t}\right) \times \\
& P\left(S_{t} \mid v_{1}, \ldots, v_{t}\right) \\
\propto & f\left(v_{t+1}, \ldots, v_{t}, S_{t+2}, \ldots, S_{T} \mid v_{1}, \ldots, v_{t}, S_{t}, S_{t+1}\right) \times \\
& P\left(S_{t+1} \mid S_{t}\right) \times P\left(S_{t} \mid v_{1}, \ldots, v_{t}\right) \\
\propto & P\left(S_{t+1} \mid S_{t}\right) \times P\left(S_{t} \mid v_{1}, \ldots, v_{t}\right) .
\end{aligned}
$$

The first and second proportions in equation (10) are simply applications of Bayes'

theorem. Because the density $f\left(v_{t+1} \ldots, v_{T}, S_{t+2}, \ldots, S_{T} \mid v_{1}, \ldots, v_{t}, S_{t}, S_{t+1}\right)$ is independent of $S_{t}$, it can be subsumed into the constant of proportionality, which can easily be recovered in order to draw states. As shown in equation (10), the only necessary inputs are the transition probabilities and the filtered probabilities conditional on the contemporaneous data.

Priors and posteriors for $\beta$ coefficients

Following Albert and Chib (1993), the prior for $\beta$ is diffuse and the initial value for $\beta$ in the first cycle of the Gibbs sampler is the ordinary least square estimate from the regression of the initial draw of $y^{*}$ on the right-hand variables. Like Albert and Chib (1993, p. 671), we use a flat uninformative prior for $\beta$, because our initial draw of $y^{*}$ is uninformative. For this reason, we do not wish to allow a prior distribution around the starting OLS estimate to influence the posterior distribution. 
With $\sum_{T}$ denoting the diagonal matrix with entries from the vector $\left(\sigma_{S 1_{t}}^{2}, t=1, \ldots, \mathrm{T}\right)$, the posterior distribution for $\beta$ is the multivariate normal distribution for generalized least squares coefficients:

$$
\beta \sim \mathrm{N}\left(\left(\mathrm{X}^{\prime} \sum_{T}^{-1} \mathrm{X}\right)^{-1} \mathrm{X}^{\prime} \sum_{T}^{-1} y^{*},\left(\mathrm{X}^{\prime} \sum_{T}^{-1} \mathrm{X}\right)^{-1}\right)
$$

where the matrix $X$ is understood to include the lagged dependent variable and intercept dummies for $S 2$ and $(1-S 2)$. Hence the $\beta$ coefficients described here include the autoregressive and drift coefficients.

Generating latent variables, $y_{\mathrm{t}}^{*}$

The initial values of $y_{t}^{*}, t=1, \ldots, \mathrm{T}$ are drawn from $f\left(y_{t}^{*} \mid y_{t-1}^{*}, y_{t} \in\right.$ cat. $\left.j\right)$. In this case,

$$
y_{t}^{*} \sim \mathrm{N}\left(\rho y_{t-1}^{*}+X_{t-1}^{\prime} \beta, \sigma_{S t}^{2}\right)
$$

with truncation such that $y_{t}^{*} \in\left(c_{j-1}, c_{j}\right)$.These expressions imply that the disturbance, $\varepsilon_{t}$, is in the interval $\left[-\rho y_{t-1}^{*}-\mathrm{X}_{t-1}^{\prime} \beta+c_{j-1}, \rho y_{t-1}^{*}-\mathrm{X}_{t-1}^{\prime} \beta+c_{j}\right)$. Denote this interval as $\left[l_{t}, u_{t}\right)$. The standardized shock, $\varepsilon_{t} / \sigma_{s t}^{2}$ is in the interval $\left[-\rho y_{t-1}^{*}-\mathrm{X}_{t-1}^{\prime} \beta+c_{j-1}, \rho y_{t-1}^{*}-\mathrm{X}_{t-1}^{\prime} \beta+c_{j}\right]$. Let $\Phi$ denote the cumulative normal density function. To sample from the truncated normal, we first draw a uniform variable, $v_{t}$, from the interval $\left[\Phi\left(l_{t} / \sigma s_{1 t}\right), \Phi\left(u_{t} / \sigma_{s_{1 t}}\right)\right]$. The truncated normal draw for the standardized shock is then $\Phi^{-1}\left(v_{t}\right)$.

We take subsequent draws from

$$
f\left(y_{t}^{*(i+1)} \mid y_{t-1}^{*(i+1)}, y_{t+1}^{*(i)}, y_{t} \in \text { cat.j }\right)
$$

where, as in equation (5), superscript $i$ denotes the $i^{\text {th }}$ cycle of the Gibbs sampler. We use the density from equation (11), because sampling the entire vector jointly from $f\left(y_{1}^{*}, \ldots, y_{T}^{*} \mid Y_{T}\right)$ 
would require evaluation of a density equivalent to the cumbersome likelihood function from equation (2). To draw from (11), we note that unconditionally $\left(\varepsilon_{t}, \varepsilon_{t+1}\right)$ are distributed as independent, bivariate normals with mean zero:

$$
f\left(\varepsilon_{t}, \varepsilon_{t+1}\right)=\frac{1}{2 \pi \sigma_{s_{t}} \sigma_{S_{t+1}}} \exp \left\{-.5 \varepsilon_{t}^{2} / \sigma_{S_{t}}^{2}-.5 \varepsilon_{t+1}^{2} / \sigma_{S_{t+1}}^{2}\right\} .
$$

Given equation (1), we can write

$$
\begin{aligned}
y_{t+1}^{*} & =\rho y_{t}^{*}+\mathrm{X}_{t}^{\prime} \beta+\varepsilon_{t+1} \\
& =\rho^{2} y_{t-1}^{*}+\rho \mathrm{X}_{t-1}^{\prime} \beta+\rho \varepsilon_{t}+\mathrm{X}_{t}^{\prime} \beta+\varepsilon_{t+1} .
\end{aligned}
$$

Conditional on values for $y_{t-1}^{*}$ and $y_{t+1}^{*}$, we know the particular value, denoted $r_{0}$, of $\rho \varepsilon_{t}+\varepsilon_{t+1}$. Substitute $r_{0}-\rho \varepsilon_{t}$ for $\varepsilon_{t+1}$ in the joint density of equation (12) and we find after some algebra that

$$
y_{t}^{*} \sim \mathrm{N}\left(\rho y_{t-1}^{*}+\mathrm{X}_{t-1}^{\prime} \beta+\frac{\rho r_{0} \sigma_{S_{t}}^{2}}{\rho^{2} \sigma_{S_{t}}^{2}+\sigma_{S_{t+1}}^{2}}, \frac{\sigma_{S_{t+1}}^{2} \sigma_{S_{t}}^{2}}{\rho^{2} \sigma_{S_{t}}^{2}+\sigma_{S_{t+1}}^{2}}\right)
$$

We then draw $y_{t}^{*}$ as a truncated normal as described above.

\section{Drawing cut-off coefficients}

With five discrete categories for financial conditions, we need to draw four cut-off coefficients for the vector $c_{j}, j=0, \ldots, 5$, where $c_{0}=-\infty, c_{2}=0$ and $c_{5}=\infty$. For the discrete variable, $y_{t}$ is in category $j$ when the latent variable $y_{t}^{*} \in\left(c_{j-1}, c_{j}\right)$. The relevant conditioning information for the draw of $c_{j}$ is $\left\{c_{j-1}, Z_{t}, t=1, \ldots, \mathrm{T}\right\}$. Given this information, the posterior distribution for $c_{j}$ is uniform on the interval $\left(c_{j-1}, \min \left\{\mathrm{Z}_{t}: \mathrm{Z}_{t} \in\right.\right.$ cat. $\left.\left.j+1\right\}\right)$.

\section{Estimates of Parameters Other Than Slope Coefficients}

The cut-off coefficients from Table B.1 provide information on the symmetry or asymmetry of the category boundaries around the "normal" financial conditions category. We look for symmetry by comparing the distance between the upper bound of the "normal" category and the lower bound of the "financial euphoria" category with the distance between the lower 
bound of the "normal" category and the upper bound of the "severe distress" category. That is, we ask whether shocks of the same magnitude will move financial conditions from normal to either extreme, or whether a larger shock is needed in one direction. The comparison is between $0-c_{1}$ and $c_{3}-c_{2}$. The posterior means from Table B.1 indicate that for all specifications the magnitude of the shock required to move financial conditions from the bottom boundary of the normal range to the upper boundary of the severe distress range is about 0.7 , which is greater than the magnitude of the shock needed to move financial conditions from the upper boundary of normal to the lower boundary of financial euphoria, which is about 0.5 . This asymmetry suggests that large negative shocks are more common than large positive shocks, a distributional feature that is common among financial phenomena.

The transition probabilities $(p+q)$ sum to little more than one, which indicates that the states are not strongly serially correlated (Table B.2). Episodes of high volatility are not clustered in a way that make it valuable to estimate two transition probabilities instead of setting $q=(1-p)$. In this way the latent variable for financial conditions does not act like most other financial data, where volatility clustering is prevalent. Hence, the estimates for the cut-off coefficients and transition probabilities show that in some ways the latent variable for financial conditions behaves very much like other financial variables, but does not on other dimensions. Note that since our explanatory variables are macroeconomic, not financial, variables, the latent variable is not biased to behave as a financial variable. 
Table B.1

Cut-off Constants for Category Boundaries (Models of Table 2)

\begin{tabular}{|l|l|l|l|l|}
\hline Index: & Qualitative & Qualitative & Quantitative & Quantitative \\
\hline Estimation Period: & $1792-1997$ & $1792-1997$ & $1870-1997$ & $1870-1997$ \\
\hline War Dummies & No & Yes & No & Yes \\
\hline Severe/Moderate Distress & & & & -0.67 \\
95\% interval & $(-0.83,-0.48)$ & $(-0.83,-0.48)$ & $(-0.86,-0.51)$ & $(-0.96,-0.56)$ \\
Moderate Distress/Normal & Fixed at 0 & Fixed at 0 & Fixed at 0 & Fixed at 0 \\
95\% interval & & & & \\
Normal/Expansion & 0.75 & $(0.63,0.85)$ & $(0.67,0.96)$ & $(0.69,1.00)$ \\
95\% interval & $(0.63,0.85)$ & 1.19 & 1.35 & 1.31 \\
$\begin{array}{l}\text { Expansion/Euphoria } \\
\text { 95\% interval }\end{array}$ & $(1.04,1.37)$ & $(1.03,1.36)$ & $(1.13,1.60)$ & $(1.13,1.52)$ \\
\hline
\end{tabular}

Table B.2

Transition Probabilities for Markov Switching (Models of Table 2)

\begin{tabular}{|l|r|r|l|l|}
\hline Index: & Qualitative & Qualitative & Quantitative & Quantitative \\
\hline Estimation Period: & $1792-1997$ & $1792-1997$ & $1870-1997$ & $1870-1997$ \\
\hline War Dummies & No & Yes & No & Yes \\
\hline $\begin{array}{l}\text { Trans. Prob. p1 } \\
\text { 95\% interval }\end{array}$ & 0.76 & 0.76 & 0.77 & 0.81 \\
Trans. Prob. q1 & $(0.68,0.84)$ & $(0.68,0.84)$ & $(0.69,0.86)$ & $(0.71,1.00)$ \\
95\% interval & 0.29 & 0.29 & 0.30 & 0.35 \\
Trans. Prob. p2 & $(0.18,0.41)$ & $(0.18,0.41)$ & $(0.19,0.42)$ & $(0.18,0.92)$ \\
95\% interval & 0.65 & 0.65 & 0.65 & 0.65 \\
Trans. Prob. q2 & $(0.59,0.72)$ & $(0.59,0.72)$ & $(0.59,0.72)$ & $(0.59,0.72)$ \\
95\% interval & 0.36 & 0.36 & 0.37 & 0.37 \\
Intercept, S2=0 & $(0.28,0.45)$ & $(0.27,0.45)$ & $(0.28,0.45)$ & $(0.28,0.45)$ \\
95\% interval & 0.27 & 0.27 & 0.19 & 0.22 \\
Intercept, S1=1 & $(0.01,0.53)$ & $(0.01,0.53)$ & $(0.05,0.31)$ & $(-0.04,0.50)$ \\
95\% interval & 0.38 & 0.38 & 0.29 & 0.32 \\
\hline
\end{tabular}

Note: The variances are fixed at 0.10 when $\mathrm{S} 1=0$ and 0.50 when $\mathrm{S} 1=1$. 
Table 1a

Qualitative Index of Financial Conditions, 1790-1997

\begin{tabular}{|c|c|c|c|c|}
\hline $\begin{array}{l}\text { Severe } \\
\text { Distress (12) }\end{array}$ & $\begin{array}{l}\text { Moderate Distress } \\
\text { (48) }\end{array}$ & Normal (103) & $\begin{array}{l}\text { Moderate } \\
\text { Expansion (35) }\end{array}$ & Euphoria (9) \\
\hline 1797 & 1796 & 1790 & 1791 & 1795 \\
\hline 1819 & 1798 & $1792-94$ & 1804 & 1805 \\
\hline 1837 & 1808-09 & $1799-1803$ & 1806 & 1824 \\
\hline 1857 & 1812 & 1807 & 1813 & 1919 \\
\hline 1873 & $1814-16$ & $1810-11$ & 1823 & 1928 \\
\hline 1874 & 1818 & 1817 & $1835-36$ & $1945-47$ \\
\hline 1876 & 1820 & 1821 & 1847 & 1950 \\
\hline 1893 & 1822 & $1827-28$ & 1850 & \\
\hline 1894 & $1825-26$ & $1830-32$ & 1852 & \\
\hline 1896 & 1829 & 1834 & $1862-64$ & \\
\hline 1931 & 1833 & $1843-45$ & $1879-81$ & \\
\hline \multirow{32}{*}{1932} & $1838-42$ & 1849 & 1899 & \\
\hline & 1846 & 1851 & 1902 & \\
\hline & 1848 & 1853 & $1905-06$ & \\
\hline & 1854 & $1855-56$ & 1916 & \\
\hline & 1858 & $1859-60$ & 1925 & \\
\hline & 1861 & $1865-68$ & $1940-44$ & \\
\hline & $1869-70$ & $1871-72$ & $1965-66$ & \\
\hline & 1875 & 1878 & $1968-69$ & \\
\hline & 1877 & 1882 & $1977-78$ & \\
\hline & $1883-85$ & $1886-92$ & $1996-97$ & \\
\hline & 1895 & $1897-98$ & & \\
\hline & 1903 & 1900-01 & & \\
\hline & 1907-08 & 1904 & & \\
\hline & 1914 & $1909-13$ & & \\
\hline & 1921 & 1915 & & \\
\hline & 1930 & $1917-18$ & & \\
\hline & 1933 & 1920 & & \\
\hline & 1938 & $1922-24$ & & \\
\hline & 1974 & $1926-27$ & & \\
\hline & $1981-82$ & 1929 & & \\
\hline & 1984 & $1934-37$ & & \\
\hline & $1986-87$ & 1939 & & \\
\hline & $1990-91$ & $1948-49$ & & \\
\hline & & $1951-64$ & & \\
\hline & & 1967 & & \\
\hline & & $1970-73$ & & \\
\hline & & $1975-76$ & & \\
\hline & & $1979-80$ & & \\
\hline & & 1983 & & \\
\hline & & 1985 & & \\
\hline & & $1988-89$ & & \\
\hline & & $1992-95$ & & \\
\hline
\end{tabular}


Table $1 \mathrm{~b}$

Quantitative Index of Financial Conditions, 1870-1997

$\begin{array}{lllll}\begin{array}{l}\text { Severe } \\ \text { Distress (8) }\end{array} & \begin{array}{l}\text { Moderate Distress } \\ (20)\end{array} & \text { Normal (72) } & \begin{array}{l}\text { Moderate } \\ \text { Expansion (18) }\end{array} & \begin{array}{l}\text { Euphoria (10) } \\ \hline 1878\end{array} \\ 1931-32 & 1873-77 & 1870-72 & 1903-07 & 1917-19 \\ 1982-86 & 1893 & 1879-83 & 1909-13 & 1943-48 \\ & 1921-22 & 1885-92 & 1916 & 1951 \\ & 1930 & 1894-1902 & 1920 & \\ & 1933-34 & 1908 & 1942 & \\ & 1938 & 1914-15 & 1950 & \\ & 1981 & 1923-29 & 1952-55 & \\ & 1987-92 & 1935-37 & & \\ & & 1939-41 & & \\ & & 1949 & & \\ & & 1956-80 & & \\ & & 1993-97 & \end{array}$


Table 2

Probit Model Estimates for Alternative Indexes of Financial Conditions

\begin{tabular}{|c|c|c|c|c|}
\hline Index: & Qualitative & Qualitative & Quantitative & Quantitative \\
\hline $\begin{array}{l}\mathrm{E}(\Delta \ln \mathrm{P}), 1792-1869 \\
95 \% \text { interval } \\
90 \% \text { interval }\end{array}$ & $\begin{array}{c}-0.08 \\
(-0.20,0.03) \\
(-0.18,0.01)\end{array}$ & $\begin{array}{c}-0.08 \\
(-0.20,0.04) \\
(-0.18,0.02)\end{array}$ & $\begin{array}{c}-0.06 \\
(-0.19,0.07) \\
(-0.17,0.05)\end{array}$ & $\begin{array}{c}-0.07 \\
(-0.19,0.05) \\
(-0.17,0.04)\end{array}$ \\
\hline $\begin{array}{l}\mathbf{P}^{\mathrm{ue}}, \mathbf{1 7 9 2 - 1 8 6 9} \\
\mathbf{9 5 \%} \text { interval } \\
\mathbf{9 0 \%} \text { interval }\end{array}$ & $\begin{array}{c}1.91 \\
(-0.28,4.08) \\
(0.10,3.72)\end{array}$ & $\begin{array}{c}2.11 \\
(0.00,4.25) \\
(0.32,3.92)\end{array}$ & $\begin{array}{c}1.98 \\
(-0.28,4.35) \\
(0.05,3.95)\end{array}$ & $\begin{array}{c}2.29 \\
(0.06,4.50) \\
(0.39,4.15)\end{array}$ \\
\hline $\begin{array}{l}\mathrm{E}(\Delta \ln \mathrm{P}), 1870-1933 \\
95 \% \text { interval } \\
90 \% \text { interval }\end{array}$ & $\begin{array}{c}-0.15 \\
(-0.26,-0.04) \\
(-0.25,-0.05)\end{array}$ & $\begin{array}{c}-0.15 \\
(-0.27,-0.04) \\
(-0.25,-0.05)\end{array}$ & $\begin{array}{c}-0.06 \\
(-0.19,0.06) \\
(-0.17,0.04)\end{array}$ & $\begin{array}{c}-0.07 \\
(-0.19,0.05) \\
(-0.17,0.03)\end{array}$ \\
\hline $\begin{array}{l}P^{\mathrm{ue}}, \mathbf{1 8 7 0 - 1 9 3 3} \\
\mathbf{9 5 \%} \text { interval } \\
90 \% \text { interval }\end{array}$ & $\begin{array}{c}2.62 \\
(-0.58,5.78) \\
(-0.09,5.33)\end{array}$ & $\begin{array}{c}2.71 \\
(-0.43,5.92) \\
(0.04,5.43)\end{array}$ & $\begin{array}{c}6.27 \\
(2.78,10.09) \\
(3.27,9.46)\end{array}$ & $\begin{array}{c}6.62 \\
(3.18,10.28) \\
(3.72,9.68)\end{array}$ \\
\hline $\begin{array}{l}\mathrm{E}(\Delta \pi), 1934-79 \\
95 \% \text { interval } \\
90 \% \text { interval }\end{array}$ & $\begin{array}{c}-0.00 \\
(-0.05,0.05) \\
(-0.04,0.04)\end{array}$ & $\begin{array}{c}0.00 \\
(-0.05,0.05) \\
(-0.04,0.05)\end{array}$ & $\begin{array}{c}0.03 \\
(-0.02,0.08) \\
(-0.01,0.07)\end{array}$ & $\begin{array}{c}0.04 \\
(-0.01,0.09) \\
(-0.00,0.08)\end{array}$ \\
\hline $\begin{array}{l}\pi^{\mathrm{ue}}, \mathbf{1 9 3 4 - 7 9} \\
95 \% \text { interval } \\
90 \% \text { interval }\end{array}$ & $\begin{array}{c}0.03 \\
(-0.03,0.09) \\
(-0.02,0.08)\end{array}$ & $\begin{array}{c}0.04 \\
(-0.02,0.09) \\
(-0.01,0.08)\end{array}$ & $\begin{array}{c}0.02 \\
(-0.04,0.08) \\
(-0.03,0.07)\end{array}$ & $\begin{array}{c}0.02 \\
(-0.04,0.08) \\
(-0.03,0.07)\end{array}$ \\
\hline $\begin{array}{l}\mathrm{E}(\Delta \pi), 1980-97 \\
95 \% \text { interval } \\
90 \% \text { interval }\end{array}$ & $\begin{array}{c}-0.05 \\
(-0.11,-0.00) \\
(-0.10,-0.01)\end{array}$ & $\begin{array}{c}-0.06 \\
(-0.11,-0.00) \\
(-0.10,-0.01)\end{array}$ & $\begin{array}{c}-0.08 \\
(-0.14,-0.02) \\
(-0.13,-0.03)\end{array}$ & $\begin{array}{c}-0.09 \\
(-0.14,-0.03) \\
(-0.14,-0.04)\end{array}$ \\
\hline $\begin{array}{l}\pi^{\mathrm{ue}}, \mathbf{1 9 8 0 - 9 7} \\
\mathbf{9 5 \%} \text { interval } \\
\mathbf{9 0 \%} \text { interval }\end{array}$ & $\begin{array}{c}-0.01 \\
(-0.14,0.12) \\
(-0.13,0.09)\end{array}$ & $\begin{array}{c}-0.02 \\
(-0.15,0.12) \\
(-0.13,0.09)\end{array}$ & $\begin{array}{c}0.18 \\
(0.01,0.38) \\
(0.03,0.34)\end{array}$ & $\begin{array}{c}0.18 \\
(0.02,0.37) \\
(0.04,0.34)\end{array}$ \\
\hline $\begin{array}{l}\Delta \ln \mathrm{GNP}, 1792-1874 \\
95 \% \text { interval } \\
90 \% \text { interval }\end{array}$ & $\begin{array}{c}0.01 \\
(-0.02,0.03) \\
(-0.01,0.02)\end{array}$ & $\begin{array}{c}0.01 \\
(-0.02,0.03) \\
(-0.01,0.02)\end{array}$ & $\begin{array}{c}0.01 \\
(-0.02,0.03) \\
(-0.01,0.03)\end{array}$ & $\begin{array}{c}0.01 \\
(-0.01,0.03) \\
(-0.01,0.03)\end{array}$ \\
\hline $\begin{array}{l}\Delta \ln \text { GNP, } 1875-1933 \\
95 \% \text { interval } \\
90 \% \text { interval }\end{array}$ & $\begin{array}{c}0.04 \\
(0.02,0.06) \\
(0.02,0.06)\end{array}$ & $\begin{array}{c}0.04 \\
(0.02,0.06) \\
(0.02,0.06)\end{array}$ & $\begin{array}{c}0.02 \\
(-0.00,0.05) \\
(0.00,0.05)\end{array}$ & $\begin{array}{c}0.02 \\
(-0.01,0.05) \\
(-0.00,0.04)\end{array}$ \\
\hline $\begin{array}{l}\Delta \ln \mathrm{GNP}, 1934-97 \\
95 \% \text { interval } \\
90 \% \text { interval }\end{array}$ & $\begin{array}{c}-0.00 \\
(-0.03,0.03) \\
(-0.02,0.02)\end{array}$ & $\begin{array}{c}-0.00 \\
(-0.03,0.02) \\
(-0.03,0.02)\end{array}$ & $\begin{array}{c}0.01 \\
(-0.02,0.04) \\
(-0.01,0.03)\end{array}$ & $\begin{array}{c}0.00 \\
(-0.02,0.03) \\
(-0.02,0.03)\end{array}$ \\
\hline $\begin{array}{l}\Delta \ln \text { Base, } 1795-1833 \\
95 \% \text { interval } \\
90 \% \text { interval }\end{array}$ & $\begin{array}{c}0.01 \\
(-0.02,0.00) \\
(-0.02,0.00)\end{array}$ & $\begin{array}{c}-0.01 \\
(-0.02,0.00) \\
(-0.02,0.00)\end{array}$ & $\begin{array}{c}-0.01 \\
(-0.03,0.00) \\
(-0.02,0.00)\end{array}$ & $\begin{array}{c}-0.01 \\
(-0.03,0.00) \\
(-0.02,0.00)\end{array}$ \\
\hline $\begin{array}{l}\Delta \ln \text { Base, } 1834-1933 \\
95 \% \text { interval } \\
90 \% \text { interval }\end{array}$ & $\begin{array}{c}0.01 \\
(-0.00,0.03) \\
(0.00,0.02)\end{array}$ & $\begin{array}{c}0.01 \\
(-0.00,0.03) \\
(0.00,0.02)\end{array}$ & $\begin{array}{c}0.01 \\
(-0.01,0.02) \\
(-0.00,0.02)\end{array}$ & $\begin{array}{c}0.01 \\
(-0.01,0.02) \\
(-0.00,0.02)\end{array}$ \\
\hline $\begin{array}{l}\Delta \ln \text { Base, } 1934-1997 \\
95 \% \text { interval } \\
90 \% \text { interval }\end{array}$ & $\begin{array}{c}0.01 \\
(-0.01,0.03) \\
(-0.01,0.03)\end{array}$ & $\begin{array}{c}0.01 \\
(-0.01,0.03) \\
(-0.00,0.03)\end{array}$ & $\begin{array}{c}0.00 \\
(-0.02,0.02) \\
(-0.01,0.02)\end{array}$ & $\begin{array}{c}0.00 \\
(-0.02,0.02) \\
(-0.01,0.02)\end{array}$ \\
\hline $\begin{array}{l}\text { Lag Dep. Var. } \\
95 \% \text { interval } \\
90 \% \text { interval }\end{array}$ & $\begin{array}{c}0.34 \\
(0.18,0.51) \\
(0.20,0.48)\end{array}$ & $\begin{array}{c}0.33 \\
(0.16,0.49) \\
(0.19,0.47)\end{array}$ & $\begin{array}{c}0.49 \\
(0.35,0.63) \\
(0.37,0.61)\end{array}$ & $\begin{array}{c}0.45 \\
(0.30,0.60) \\
(0.33,0.58)\end{array}$ \\
\hline War Dummies & No & Yes & No & Yes \\
\hline
\end{tabular}

Variable Definitions and Sources: See Table 1 and Data Appendix. 
Table 3

Regression Estimates for Alternative Financial Conditions Measures

\begin{tabular}{|c|c|c|c|c|}
\hline $\begin{array}{l}\text { Dependent } \\
\text { Variable: }\end{array}$ & $\begin{array}{l}\text { Business Failure } \\
\text { Rate }\end{array}$ & $\begin{array}{l}\text { Bank Failure } \\
\text { Rate }\end{array}$ & Real Interest Rate & $\begin{array}{l}\text { Interest Rate } \\
\text { Quality Spread }\end{array}$ \\
\hline Estimation Period: & $1870-1933$ & 1865-1932 & $1831-1933$ & $1857-1933$ \\
\hline Intercept & $\begin{array}{l}51.79 \\
(8.88) * * *\end{array}$ & $\begin{array}{l}0.007 \\
(0.002)^{* * *}\end{array}$ & $\begin{array}{l}4.34 \\
(0.47)^{* * * *}\end{array}$ & $\begin{array}{l}0.18 \\
(0.08)^{* * * *}\end{array}$ \\
\hline $\mathrm{E}(\Delta \ln \mathrm{P})$ & $\begin{array}{l}-51.39 \\
(92.23)\end{array}$ & $\begin{array}{l}-0.10 \\
(0.08)\end{array}$ & $\begin{array}{l}-6.84 \\
(14.21)\end{array}$ & $\begin{array}{l}-3.97 \\
(1.99)^{* *}\end{array}$ \\
\hline $\mathbf{P}^{\mathbf{u e}}$ & $\begin{array}{l}-130.20 \\
(49.31)^{* * *}\end{array}$ & $\begin{array}{c}-0.02 \\
(\mathbf{0 . 0 4})\end{array}$ & $\begin{array}{l}-95.74 \\
(5.83)^{* * * *}\end{array}$ & $\begin{array}{l}-- \\
--\end{array}$ \\
\hline $\mathbf{P}^{\mathrm{ue}}$ (positive) & $\begin{array}{l}-- \\
--\end{array}$ & $\begin{array}{l}-- \\
--\end{array}$ & $\begin{array}{l}-- \\
--\end{array}$ & $\begin{array}{c}1.38 \\
(1.54)\end{array}$ \\
\hline $\mathbf{P}^{\text {ue }}$ (negative) & -- & $\begin{array}{l}-- \\
--\end{array}$ & $\begin{array}{l}-- \\
--\end{array}$ & $\begin{array}{l}-6.72 \\
(1.93)^{* * *}\end{array}$ \\
\hline$\Delta \ln \mathrm{GNP}$ & $\begin{array}{l}-108.92 \\
(31.99)^{* * * *}\end{array}$ & $\begin{array}{l}-0.07 \\
(0.03)^{* *}\end{array}$ & $\begin{array}{c}1.68 \\
(4.26)\end{array}$ & $\begin{array}{l}-1.70 \\
(0.72)^{* *}\end{array}$ \\
\hline$\Delta \ln$ Mon. Base & $\begin{array}{l}-97.45 \\
(39.37)^{* *}\end{array}$ & $\begin{array}{c}0.00 \\
(0.03)\end{array}$ & $\begin{array}{l}-3.54 \\
(2.58)\end{array}$ & $\begin{array}{l}1.89 \\
(0.65)^{* * *}\end{array}$ \\
\hline Lag Dep. Var. & $\begin{array}{l}0.56 \\
(0.09)^{* * *}\end{array}$ & $\begin{array}{l}0.68 \\
(0.12)^{* * *}\end{array}$ & $\begin{array}{l}0.32 \\
(0.06)^{* * * *}\end{array}$ & $\begin{array}{l}0.66 \\
(0.06)^{* * *}\end{array}$ \\
\hline 1919 Dummy & -- & $\begin{array}{l}-- \\
--\end{array}$ & $\begin{array}{l}-- \\
--\end{array}$ & $\begin{array}{l}0.73 \\
(0.13)^{* * *}\end{array}$ \\
\hline $\begin{array}{l}\text { Adj. } R^{2} \\
\text { Durbin's-h }\end{array}$ & $\begin{array}{r}.66 \\
0.90 \\
\end{array}$ & $\begin{array}{c}.62 \\
\mathrm{~N} / \mathrm{M}\end{array}$ & $\begin{array}{c}.87 \\
1.72 *\end{array}$ & $\begin{array}{c}.91 \\
1.77^{*}\end{array}$ \\
\hline
\end{tabular}

Note: Standard errors in parentheses; $* * *, * *$, and * indicate statistically significant at $.01, .05$ and .10;

Variables:

$\mathrm{E}(\Delta \ln \mathrm{P})=$ expected log change in the price level.

$\mathrm{P}^{\mathrm{ue}}=$ price level shock.

$\Delta \ln \mathrm{GNP}=\log$ change in GNP

$\Delta \ln$ Mon. Base $=\log$ change in the monetary base

Lag Dep. Var. = lagged dependent variable

1919 Dummy $=$ dummy set equal to 1 in 1919 and subsequent years. 
Table 4

Regression Estimates for Alternative Financial Conditions Measures

\begin{tabular}{|c|c|c|c|c|}
\hline Dependent Variable: & $\begin{array}{l}\Delta \text { Business } \\
\text { Failure Rate }\end{array}$ & $\begin{array}{l}\Delta \text { Bank Failure } \\
\text { Rate }\end{array}$ & $\begin{array}{l}\Delta \text { Real Interest } \\
\text { Rate }\end{array}$ & $\begin{array}{l}\Delta \text { Interest Rate } \\
\text { Quality Spread }\end{array}$ \\
\hline Estimation Period: & 1934-1997 & 1934-1997 & $1934-1997$ & 1934-1997 \\
\hline Intercept & $\begin{array}{c}3.43 \\
(2.16)\end{array}$ & $\begin{array}{c}0.01 \\
(0.01)\end{array}$ & $\begin{array}{c}0.11 \\
(0.30)\end{array}$ & $\begin{array}{l}0.18 \\
(0.09)^{* *}\end{array}$ \\
\hline $\mathrm{E}(\Delta \pi)$ & $\begin{array}{l}-1.42 \\
(0.71)^{* *}\end{array}$ & $\begin{array}{c}0.00 \\
(0.00)\end{array}$ & $\begin{array}{l}-0.90 \\
(0.10)^{* * *}\end{array}$ & $\begin{array}{c}-0.04 \\
(0.03)\end{array}$ \\
\hline$\pi^{\mathbf{u e}}$ & $\begin{array}{l}-0.97 \\
(0.59) *\end{array}$ & $\begin{array}{l}-0.004 \\
(0.001) * * *\end{array}$ & $\begin{array}{l}-\mathbf{0 . 8 3} \\
(\mathbf{0 . 0 7}) * * *\end{array}$ & $\begin{array}{c}0.00 \\
(0.02)\end{array}$ \\
\hline$\Delta \ln \mathrm{GNP}$ & $\begin{array}{l}-82.00 \\
(27.24)^{* * *}\end{array}$ & $\begin{array}{l}-0.07 \\
(0.07)\end{array}$ & $\begin{array}{c}3.93 \\
(3.78)\end{array}$ & $\begin{array}{l}-3.92 \\
(1.17)^{* * *}\end{array}$ \\
\hline$\Delta \ln$ Mon. Base & $\begin{array}{c}0.59 \\
(27.07)\end{array}$ & $\begin{array}{l}-0.19 \\
(0.07)^{* * *}\end{array}$ & $\begin{array}{c}-3.41 \\
(3.83)\end{array}$ & $\begin{array}{c}-1.47 \\
(1.15)\end{array}$ \\
\hline Lag Dep. Var. & $\begin{array}{l}0.28 \\
(0.10)^{* * *}\end{array}$ & $\begin{array}{l}-0.48 \\
(0.08)^{* * *}\end{array}$ & $\begin{array}{c}0.03 \\
(0.06)\end{array}$ & $\begin{array}{c}0.11 \\
(0.12)\end{array}$ \\
\hline $1942-45$ & In & In & In & In \\
\hline $\begin{array}{l}\text { Adj. } R^{2} \\
\text { Durbin's-h }\end{array}$ & $\begin{array}{r}.35 \\
-1.03\end{array}$ & $\begin{array}{c}.42 \\
6.74 * * *\end{array}$ & $\begin{array}{r}.78 \\
1.11\end{array}$ & $\begin{array}{c}.16 \\
4.80 * * *\end{array}$ \\
\hline
\end{tabular}

Note: Standard errors in parentheses; $* * *, * *$, and * indicate statistically significant at $.01, .05$ and .10;

Variables:

$\mathrm{E}(\Delta \pi)=$ expected change in the inflation rate.

$\pi^{\text {ue }}=$ inflation rate shock.

$\Delta \ln \mathrm{GNP}=\log$ change in GNP

$\Delta \ln$ Mon. Base $=$ log change in the monetary base

Lag Dep. Var. = lagged dependent variable 
Figure 1: Qualitative Index and Price Level Shocks

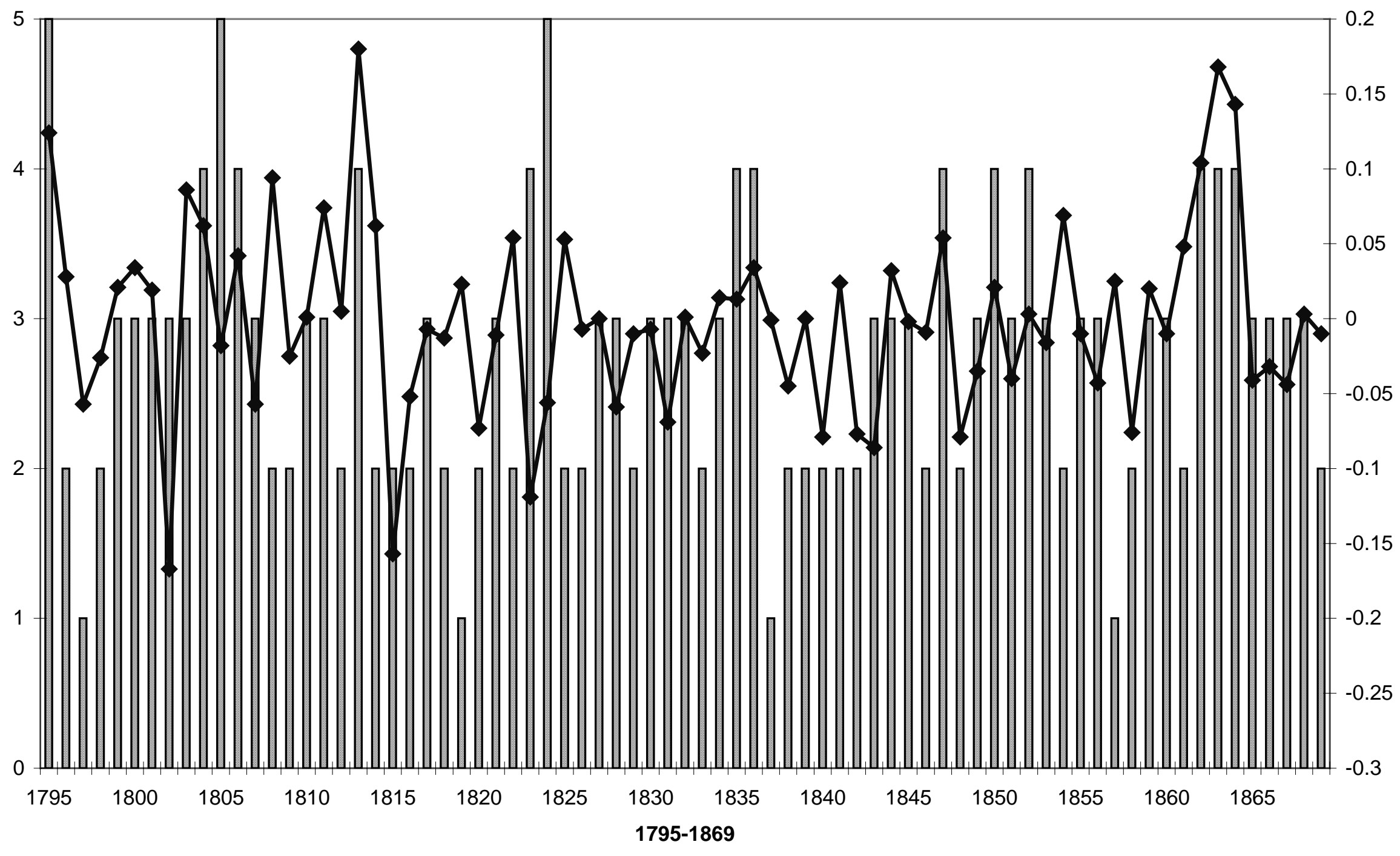


Figure 2: Quantitative Index and Price Level Shocks

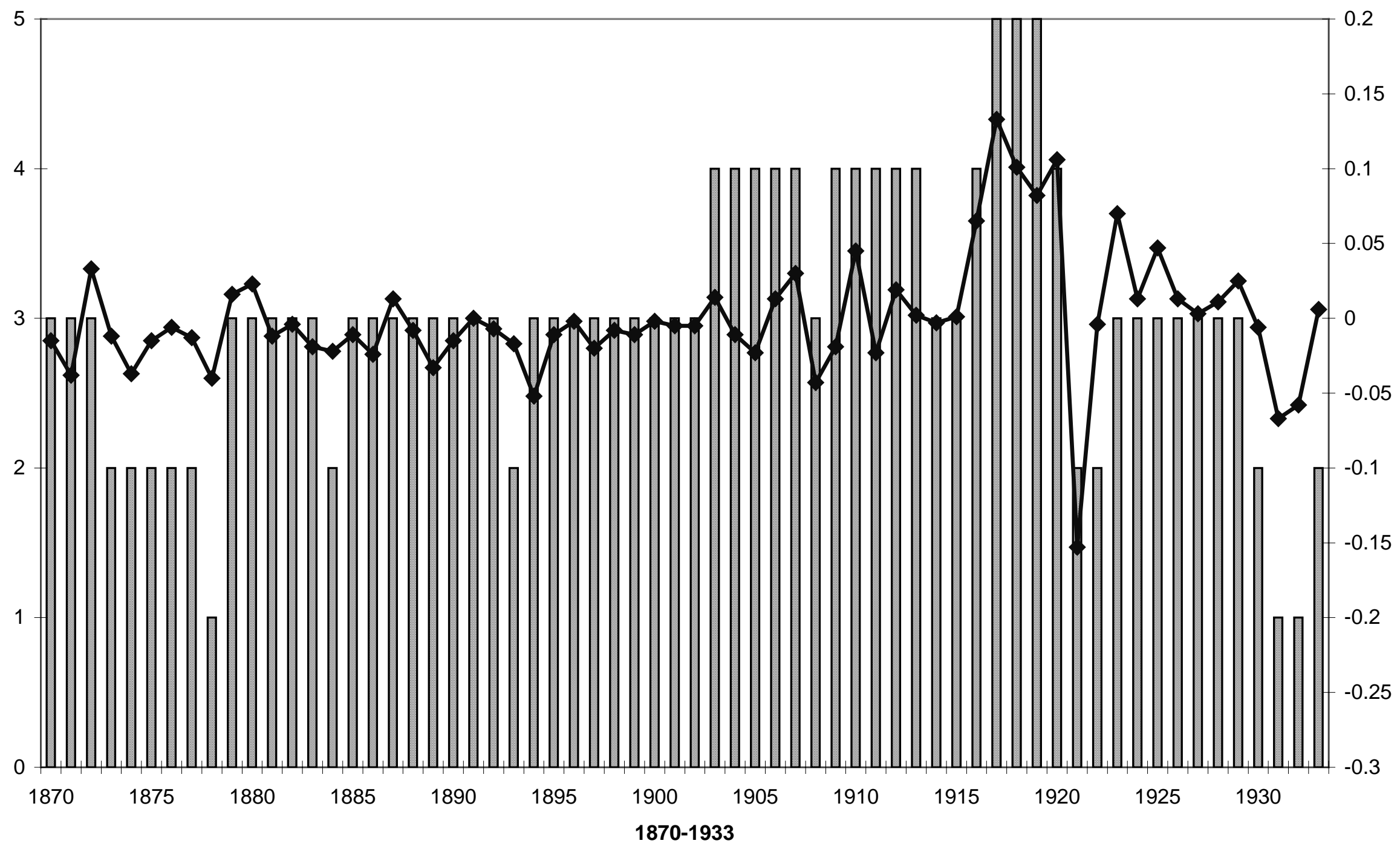


Figure 3: Qualitative Index and Price Level Shocks

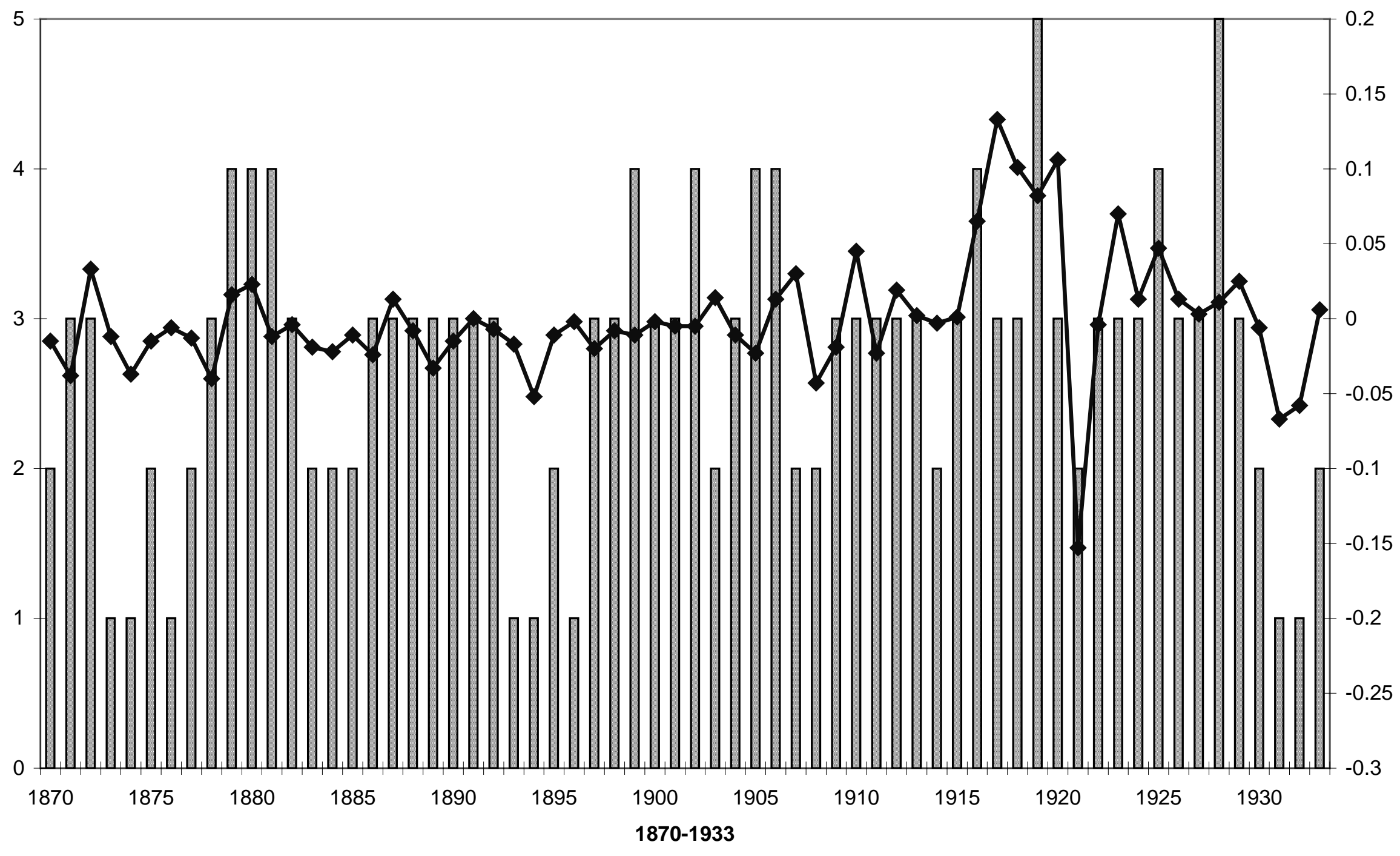


Figure 4: Quantitative Index and Inflation Shocks

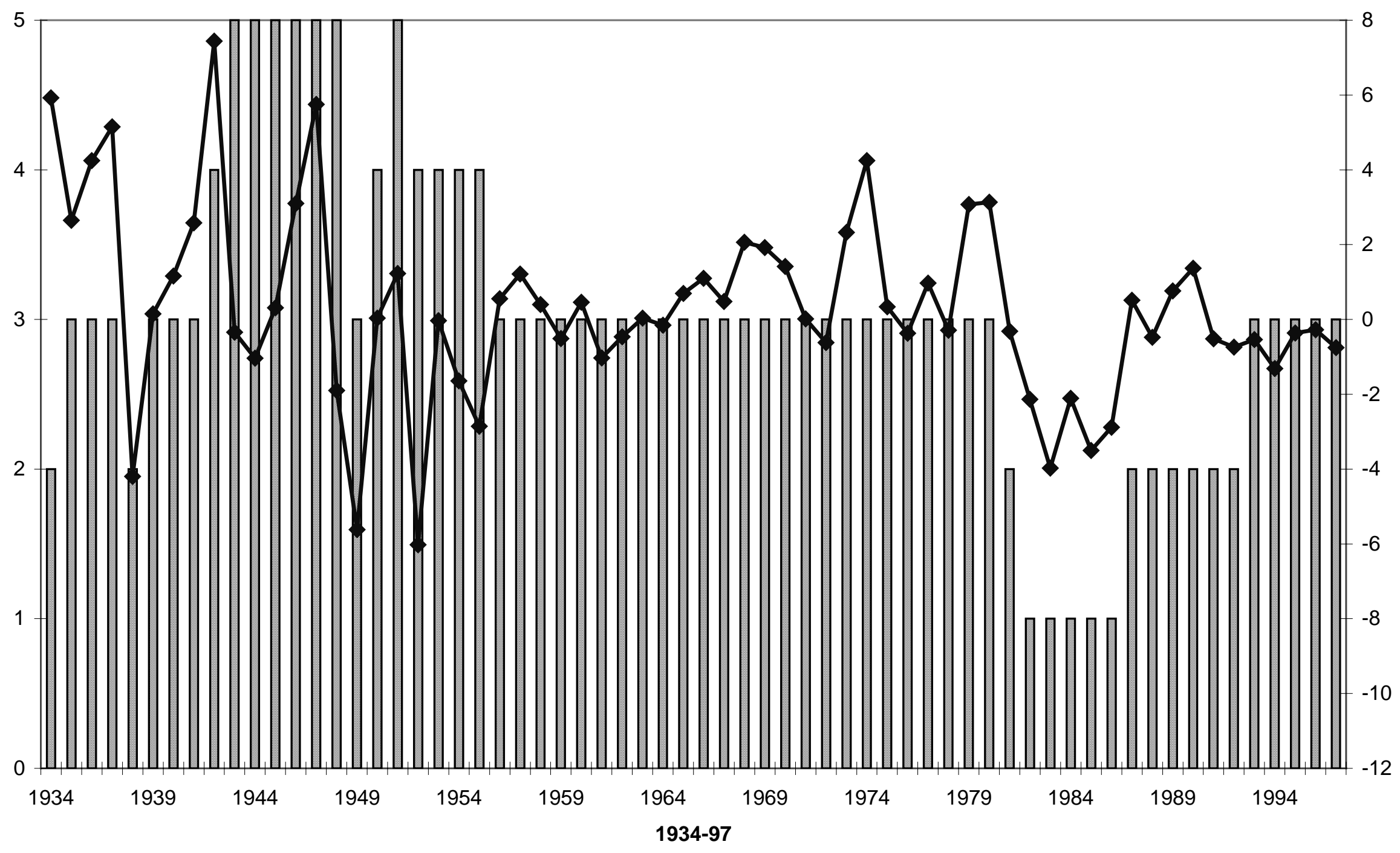


Figure 5: Qualitative Index and Inflation Shocks

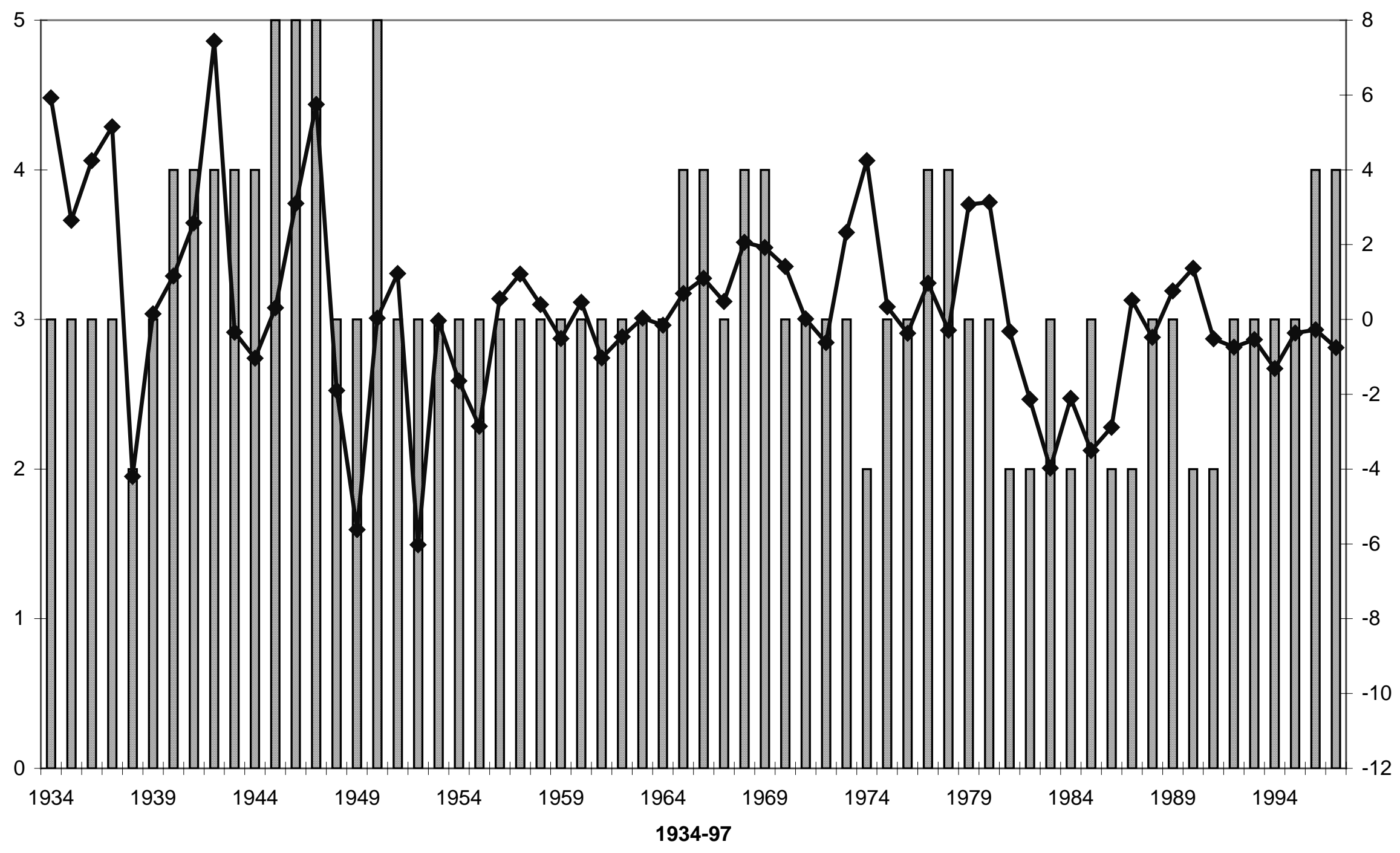


